\title{
Field Testing of Nano-PCM Enhanced Building Envelope Components
}

June 2013

Prepared by

Kaushik Biswas, Ph.D.

Phillip Childs

Jerald Atchley 


\title{
DOCUMENT AVAILABILITY
}

Reports produced after January 1, 1996, are generally available free via the U.S. Department of Energy (DOE) Information Bridge.

Web site http://www.osti.gov/bridge

Reports produced before January 1, 1996, may be purchased by members of the public from the following source.

\author{
National Technical Information Service \\ 5285 Port Royal Road \\ Springfield, VA 22161 \\ Telephone 703-605-6000 (1-800-553-6847) \\ TDD 703-487-4639 \\ Fax 703-605-6900 \\ E-mailinfo@ntis.gov \\ Web site http://www.ntis.gov/support/ordernowabout.htm
}

Reports are available to DOE employees, DOE contractors, Energy Technology Data Exchange (ETDE) representatives, and International Nuclear Information System (INIS) representatives from the following source.

Office of Scientific and Technical Information

P.O. Box 62

Oak Ridge, TN 37831

Telephone 865-576-8401

Fax 865-576-5728

E-mail reports@osti.gov

Web site http://www.osti.gov/contact.html

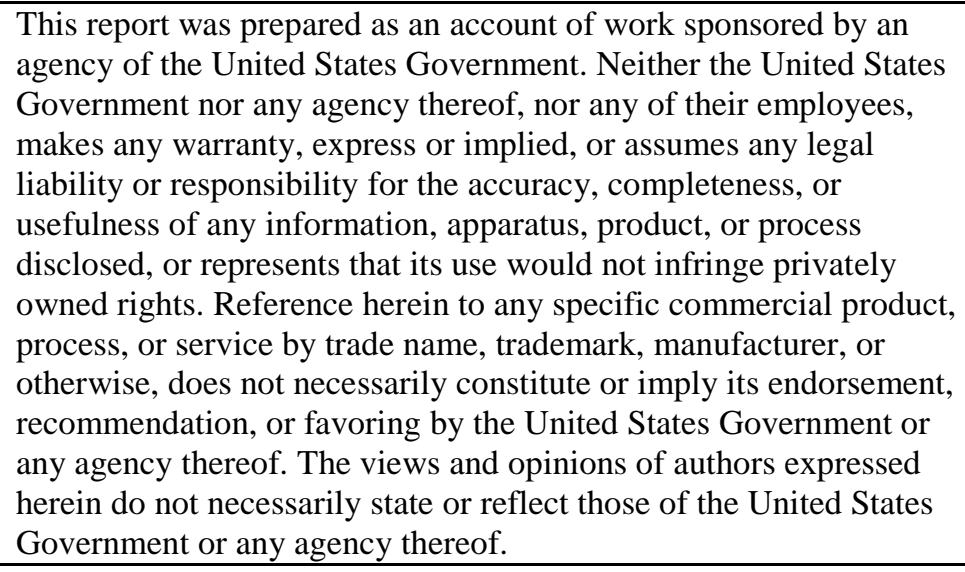




\title{
FIELD TESTING OF NANO-PCM ENHANCED BUILDING ENVELOPE COMPONENTS
}

\author{
Kaushik Biswas \\ Phillip Childs \\ Jerald Atchley
}

Date Published: June, 2013

\author{
Prepared by \\ OAK RIDGE NATIONAL LABORATORY \\ Oak Ridge, Tennessee 37831-6283 \\ managed by \\ UT-BATTELLE, LLC \\ for the \\ U.S. DEPARTMENT OF ENERGY \\ under contract DE-AC05-00OR227
}




\section{TABLE OF CONTENTS}

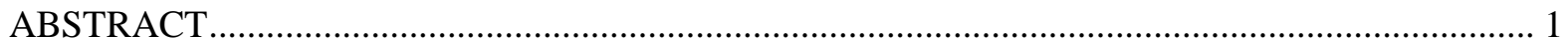

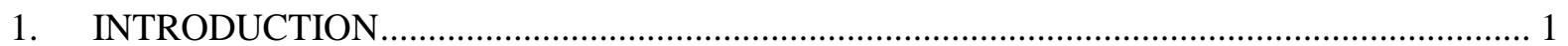

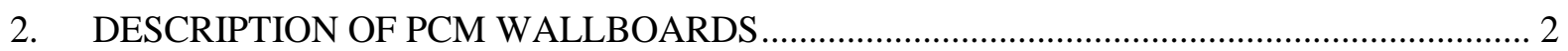

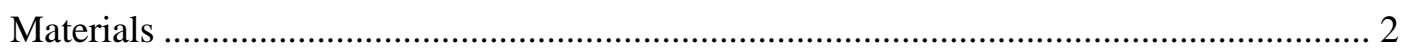

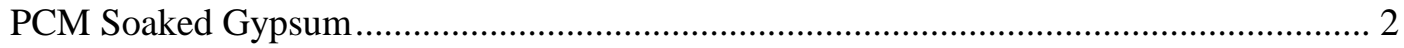

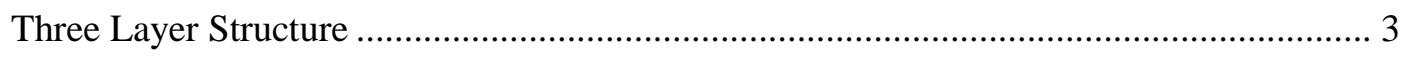

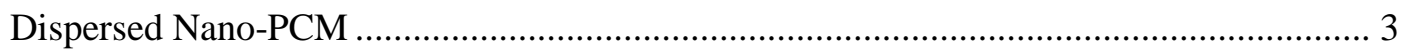

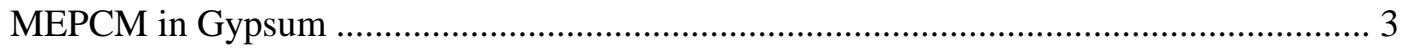

3. TEST FACILITY AND TEST WALL DETAILS ................................................................. 4

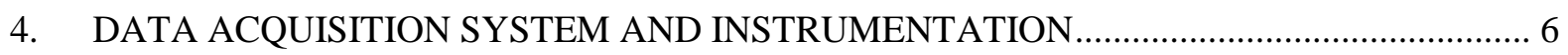

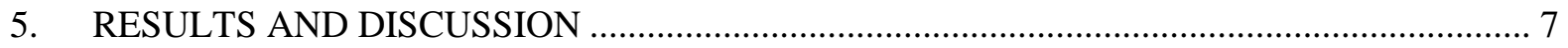

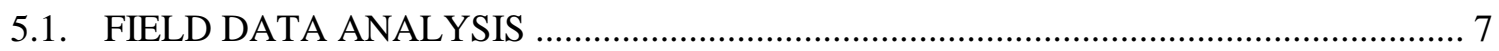

Temperature Distribution and PCM Behavior ................................................................ 7

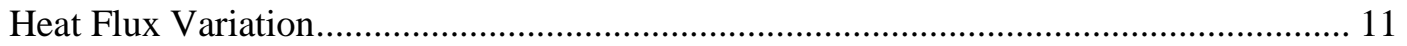

Additional Measurement Uncertainties ....................................................................... 14

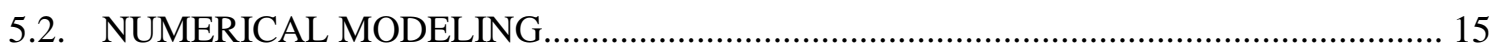

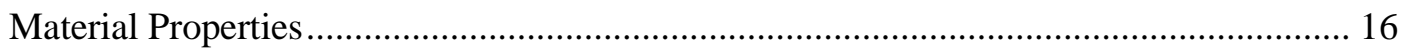

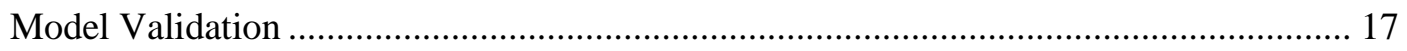

Annual Simulation in Charleston using TMY3 Data .................................................. 21

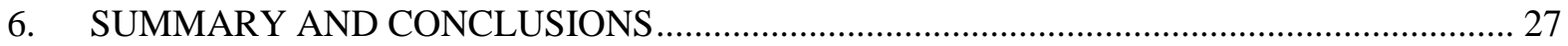

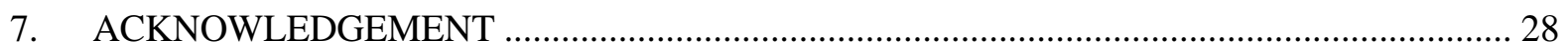

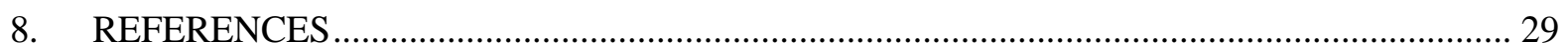




\begin{abstract}
The U.S. Department of Energy's (DOE) Building Technologies Program's goal of developing highperformance, energy efficient buildings will require more cost-effective, durable, energy efficient building envelopes. Forty-eight percent of the residential end-use energy consumption is spent on space heating and air conditioning. Reducing envelope-generated heating and cooling loads through application of phase change material (PCM)-enhanced envelope components can facilitate maximizing the energy efficiency of buildings. Field-testing of prototype envelope components is an important step in estimating their energy benefits.
\end{abstract}

An innovative phase change material (nano-PCM) was developed with PCM encapsulated with expanded graphite (interconnected) nanosheets, which is highly conducive for enhanced thermal storage and energy distribution, and is shape-stable for convenient incorporation into lightweight building components. During 2012, two test walls with cellulose cavity insulation and prototype PCM-enhanced interior wallboards were installed in a natural exposure test (NET) facility at Charleston, SC. The first test wall was divided into four sections, which were separated by wood studs and thin layers of foam insulation. Two sections contained nano-PCM-enhanced wallboards: one was a three-layer structure, in which nano-PCM was sandwiched between two gypsum boards, and the other one had PCM dispersed homogeneously throughout graphite nanosheets-enhanced gypsum board. The second test wall also contained two sections with interior PCM wallboards; one contained nano-PCM dispersed homogeneously in gypsum and the other was gypsum board containing a commercial microencapsulated PCM (MEPCM) for comparison. Each test wall contained a section covered with gypsum board on the interior side, which served as control or a baseline for evaluation of the PCM wallboards. The walls were instrumented with arrays of thermocouples and heat flux transducers.

Further, numerical modeling of the walls containing the nano-PCM wallboards were performed to determine their actual impact on wall-generated heating and cooling loads. The models were first validated using field data, and then used to perform annual simulations using Typical Meteorological Year (TMY) weather data. This article presents the measured performance and numerical analysis to evaluate the energy-saving potential of the nano-PCM-enhanced building components.

\title{
1. INTRODUCTION
}

According to the 2009 residential energy consumption survey (RECS) ${ }^{1}$ of the United States Energy Information Administration (EIA), about $48 \%$ of the total residential site-energy consumption is due to space heating and air conditioning. The U.S. Department of Energy's (DOE) Building Technologies Program's goal of developing high-performance, energy efficient buildings will require more costeffective, durable, energy efficient building envelopes. Application of phase change materials to building envelopes to take advantage of their high latent heat capacities in reducing the envelope-generated heating and cooling loads has received a lot of attention in the last two decades [Zhou et al., 2007].

Sharma et al. [2009] and Xin et al. [2009] reviewed the research and analysis of available thermal storage systems incorporating PCMs for building applications. Different approaches to PCM applications

\footnotetext{
${ }^{1}$ http://www.eia.gov/consumption/residential/data/2009/index.cfm?view=consumption
} 
in building envelopes have been investigated: PCM wallboards [Stovall and Tomlinson, 1995; Zhou et al., 2007], PCM mixed with loose-fill insulation [Shrestha et al., 2011], macro-packaged PCM in plastic pouches [Kosny et al., 2012], etc.

The subject of this article is an innovative phase change material (nano-PCM) with the PCM encapsulated in expanded graphite nanosheets, which is highly conductive, for enhanced thermal storage and energy distribution and is shape-stable for convenient incorporation into lightweight building components. This nano-PCM was incorporated in gypsum boards, which are commonly used as interior wallboards on walls in residential construction. Three prototype nano-PCM-enhanced interior wallboards were produced and were installed in a natural exposure test (NET) facility at Charleston, SC for testing. For comparison, two types of control panels were installed, gypsum board incorporating a commercial microencapsulated PCM (MEPCM) [Micronal ${ }^{\circledR}$ PCM] and standard gypsum board. In the subsequent analysis and discussion, these PCM wallboards will be referred to using the following list.

1. PCM Soaked Gypsum

2. Three Layer Structure

3. Dispersed Nano-PCM

4. MEPCM in Gypsum (also used as a control)

The first two products were installed in January 2012 and latter products were installed during July 2012. Brief descriptions of the PCM products are provided in the following section.

\section{DESCRIPTION OF PCM WALLBOARDS}

Following are brief descriptions and details about the material and thermo-physical characteristics of the PCM wallboards.

\section{Materials}

Gypsum powder was used for fabricating the gypsum boards, which were enhanced with phase change materials. A paraffin, n-heptadecane $\left(\mathrm{C}_{17} \mathrm{H}_{36}\right)$, was used as the phase change material (PCM). High thermal conductivity is a desirable characteristic of PCMs in energy storage applications, but the lower conductivity of paraffins decrease the rates of heat stored and released during the phase change processes and limiting their utility areas [Zalba et al., 2003; Sari and Karaipekli, 2007]. Exfoliated graphite nanoplatelets (xGnP) [Kim and Drzal, 2009] and expanded graphite (interconnected) nanosheets [Drzal and Fukushima, 2009] were added for increasing the thermal conductivity of the PCM wallboards for enhanced heat transfer and better utilization of PCMs.

\section{PCM Soaked Gypsum}

This PCM wallboard comprised of gypsum board which absorbed $20 \%$-by-weight n-heptadecane by soaking. The board composition was $99 \%$ gypsum and $1 \%$ exfoliated graphite nanoplatelets (xGnP) for enhanced thermal conductivity. The $\mathrm{xGnP}$ was dispersed in $1 \mathrm{~g} / \mathrm{L}$ sulfonated polystyrene by tip sonication (using ultrasound energy for particle dispersion) for one hour, and then mixed with the gypsum powder and water. The board was cured overnight at room temperature, followed by curing at $50^{\circ} \mathrm{C}$ for 48 hours. After cooling down to room temperature, the board was soaked in melted n-heptadecane, with a final PCM content of 20\%-by-weight. Figure 1 shows the heat flow data from differential scanning calorimetry (DSC) testing of n-heptadecane. During melting, the n-heptadecane is trapped in the air voids 
of the gypsum matrix without weeping due to capillary action and surface tension.

\section{Three Layer Structure}

This wallboard contained a $4 \mathrm{~mm}$ layer of nano-PCM sandwiched between two $5 \mathrm{~mm}$ layers of gypsum. The nano-PCM contains 8\%-by-weight expanded graphite nanosheets and 92\%-by-weight nheptadecane. Expanded graphite nanosheets were processed following a microwave process from expandable graphite [Drzal and Fukushima, 2009]. The weight percentage of nano-PCM in the wallboard was about $20 \%$.

Figure 1 shows the heat flow data from DSC testing of the nano-PCM. The positive heat flows represent exothermic conditions, indicating freezing phenomenon of the nano-PCM; negative heat flows indicate melting process. The DSC data provide information about the active temperature range of the PCM (where phase changes occur) and the respective latent heats. For design and analysis purposes, the smaller peaks on the left of the major melting and freezing peaks have been ignored.
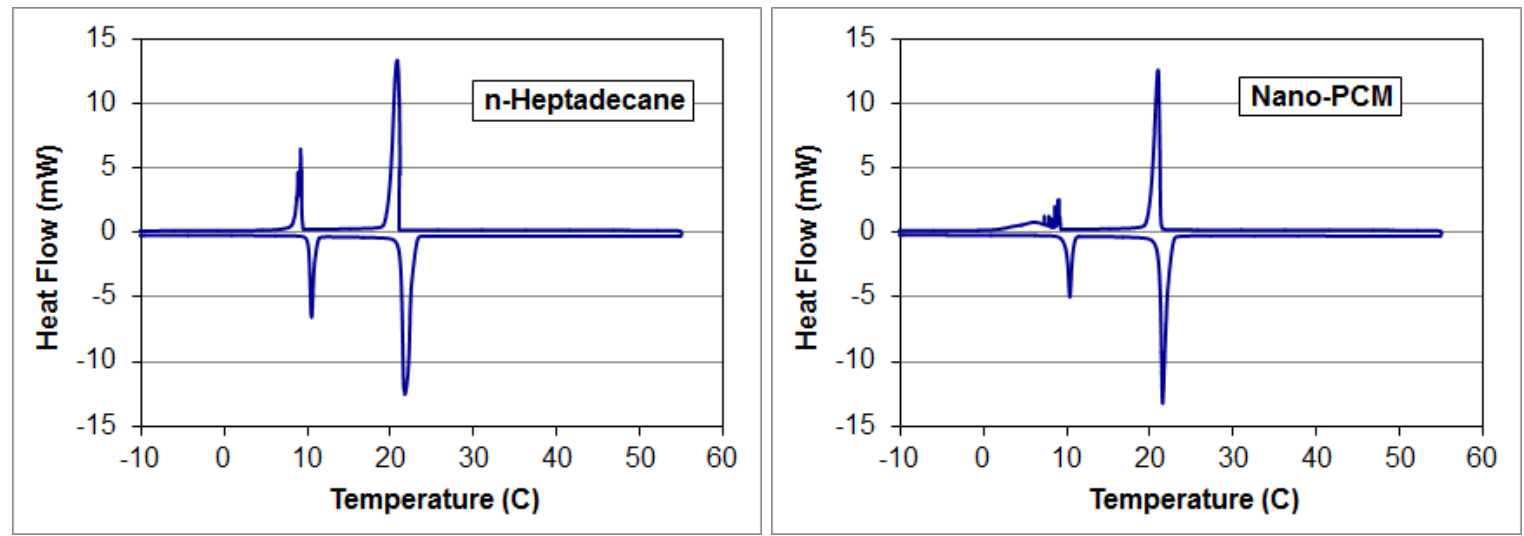

Figure 1. Melting and freezing characteristics (DSC curve) of n-heptadecane (left) and nano-PCM (n-heptadecane with $8 \%$-by-weight expanded graphite nanosheets) (right). DSC heating and cooling rate was $1^{\circ} \mathrm{C} / \mathrm{min}$.

\section{Dispersed Nano-PCM}

This board contains 20\%-by-weight nano-PCM homogeneously dispersed in gypsum board. Gypsum powder was mixed with $65 \%$-by-weight water, followed by addition of nano-PCM. This board was cured for one week at room temperature. The DSC data for this product are shown in Figure 2 (left).

\section{MEPCM in Gypsum}

This is gypsum board incorporating 20\%-by-weight MEPCM (Micronal ${ }^{\circledR 2}$ ). This board was intended for use as another control, in addition to regular gypsum board, to evaluate the performance of three prototype PCM wallboards ('PCM Soaked Gypsum', 'Three Layer Structure' and 'Dispersed nano$\mathrm{PCM}$ '). This board was cured overnight at room temperature and for five hours at $50^{\circ} \mathrm{C}$. Figure 2 (right) shows the DSC data for the 'MEPCM in Gypsum' product.

\footnotetext{
${ }^{2}$ http://worldaccount.basf.com/wa/EU/Catalog/ACIndustry/pi/BASF/segment/new building materials
} 

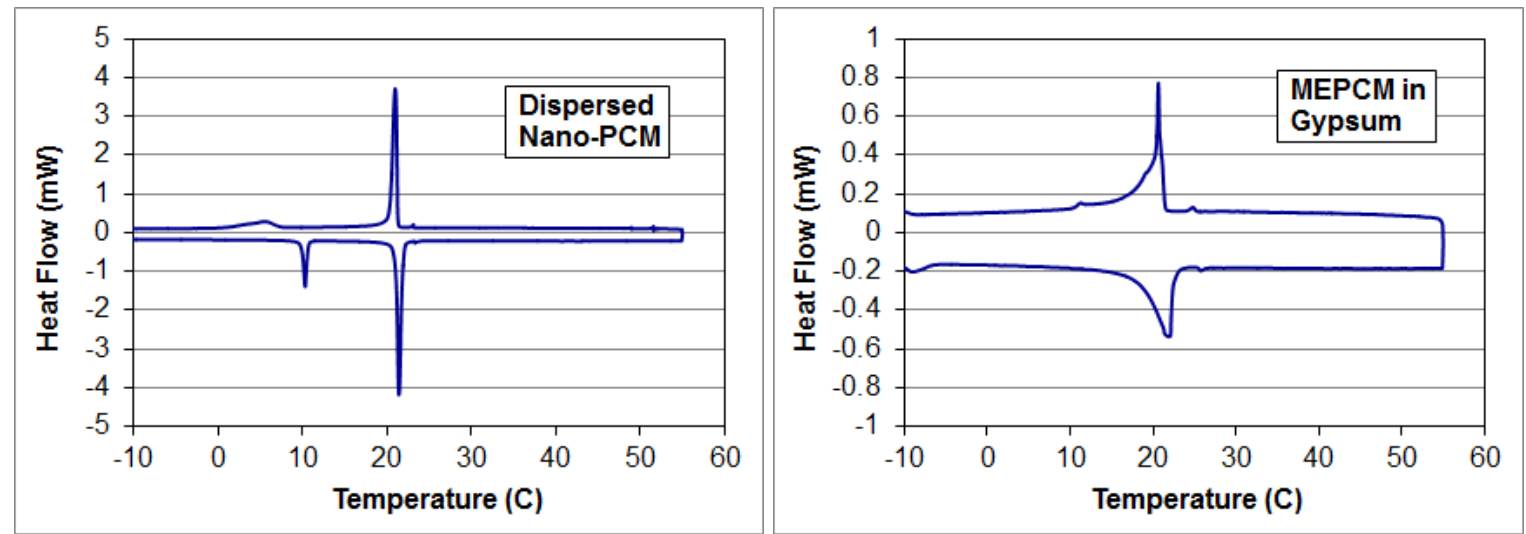

Figure 2. Melting and freezing characteristics (DSC curves) of the 'Dispersed Nano-PCM' wallboard (left) and 'MEPCM in Gypsum' wallboard (right). DSC heating and cooling rate was $1^{\circ} \mathrm{C} / \mathrm{min}$.

Table 1 lists the thermo-physical properties of the PCM wallboards. The properties were estimated using DSC data at $1^{\circ} \mathrm{C} / \mathrm{min}$ heating and cooling rates. The melting and freezing onset temperatures were determined using an integration function based on a 'tangents' method, which is included in the DSC analysis software.

Table 1. PCM Properties.

\begin{tabular}{|l|c|c|c|c|}
\hline \multirow{2}{*}{} & \multicolumn{2}{|c|}{ Latent Heat $(\mathbf{J} / \mathbf{g})$} & \multicolumn{2}{c|}{ Phase Change Onset $\left.\mathbf{(}^{\mathbf{}} \mathbf{C}\right)$} \\
\cline { 2 - 5 } & Melting & Freezing & Melting & Freezing \\
\hline PCM Soaked Gypsum & 28.2 & 27.9 & 21.2 & 21.2 \\
\hline Three Layer Structure & 29.2 & 29.3 & 21.1 & 21.3 \\
\hline Dispersed Nano-PCM & 26.9 & 26.8 & 21.1 & 21.3 \\
\hline MEPCM in Gypsum & 18.8 & 18.9 & 18.9 & 20.9 \\
\hline
\end{tabular}

\section{TEST FACILITY AND TEST WALL DETAILS}

The Syntroleum wall test is ongoing in a Natural Exposure Test (NET) facility in Charleston, SC, shown in Figure 3. NET facilities expose side-by-side roof/attic and wall assemblies to natural weathering in four different humid US climates. The data help industry develop products to avoid adverse moisture-related impacts in buildings, and are essential in validating hygrothermal and energy models. NET structures are located at ORNL and at Charleston, SC; Tacoma, WA; and Syracuse, NY. Each is temperature and humidity controlled and instrumented to measure moisture content in materials, vapor pressure, temperature, heat flux, humidity, etc. Figure 3 shows the southeast wall of the Charleston NET facility, which houses multiple side-by-side test walls. Also shown is a weather station on the southwest gable end of the building. 


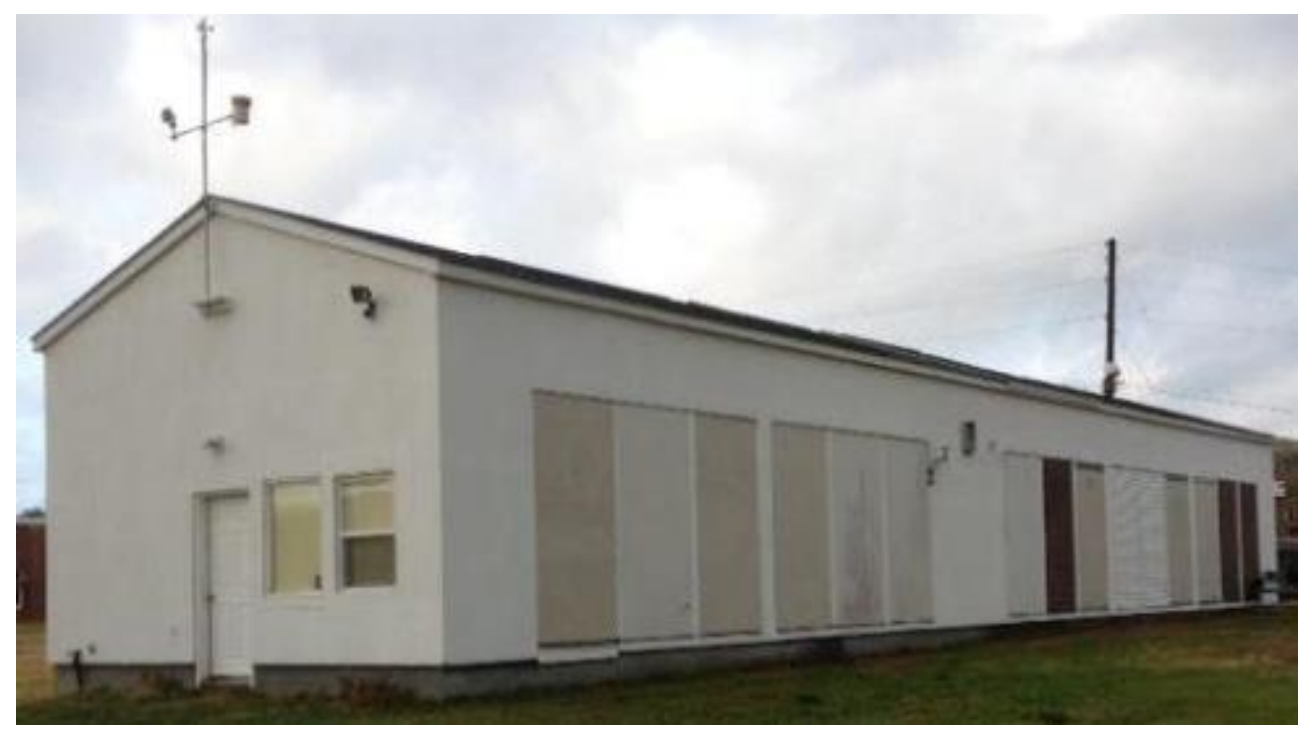

Figure 3. Charleston, SC NET facility.

The test walls were built using wood framing ( 2 x 6 studs), with oriented strand board (OSB) on the outside and the PCM wallboards on the inside. The outer side of the OSB is covered with a weather resistant barrier and vinyl siding. Figure 4 shows the installed test walls. On the left is the first wall, marked as 'Test wall 1', which was built in January 2012. It was divided into four equal sections; two sections were covered with the 'PCM Soaked Gypsum' and 'Three Layer Structure' PCM wallboards, and another section covered with standard gypsum board. The second wall, 'Test wall 2', was installed during July 2012, and contained the 'Dispersed Nano-PCM' and 'MEPCM in Gypsum' wallboards, along with a taller gypsum section.
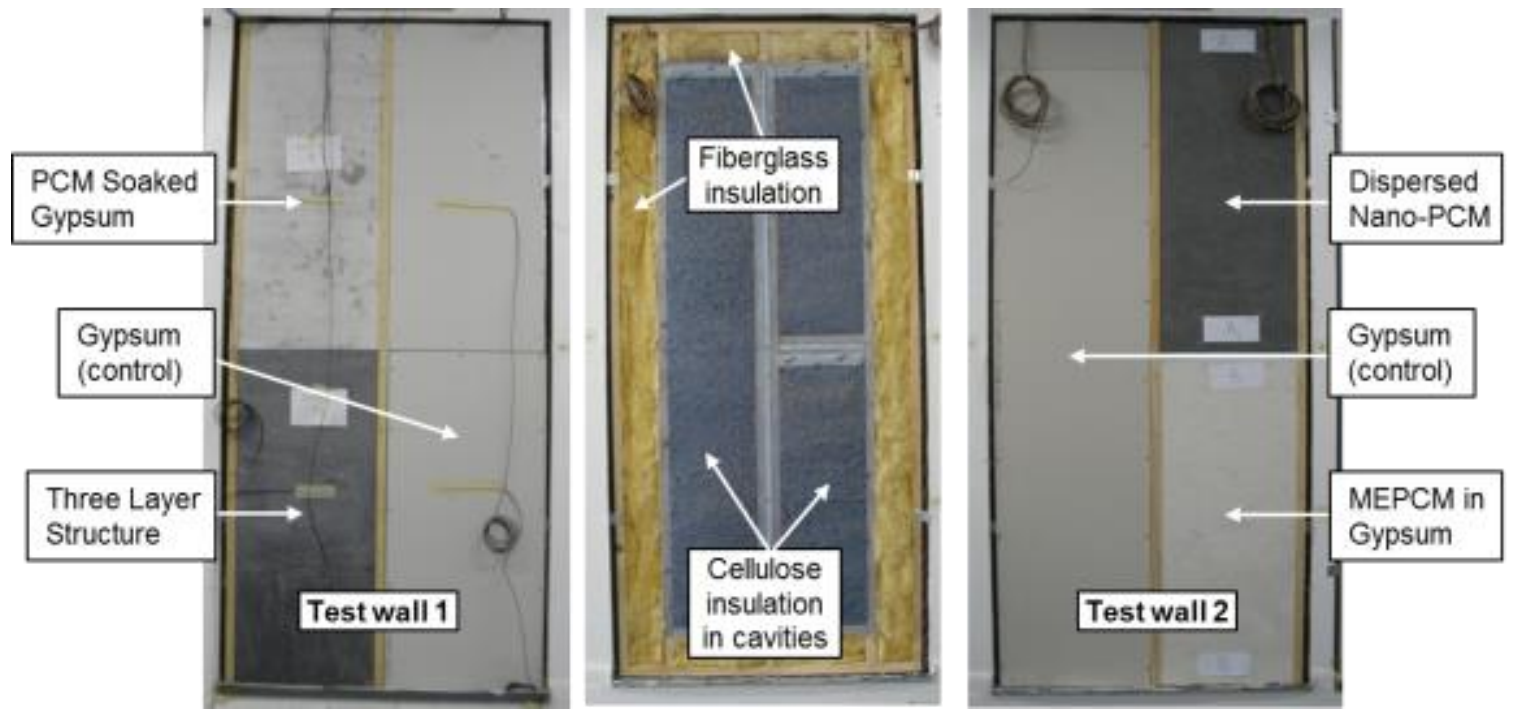

Figure 4. Test walls with the different PCM prototype wallboards.

The smaller wall cavities were about $1.1 \mathrm{~m}$ high and $0.4 \mathrm{~m}$ wide, and the taller gypsum-covered cavity in 'Test wall 2' wall was $2.2 \mathrm{~m}$ high and $0.4 \mathrm{~m}$ wide. Each cavity or section was separated from the others using wood studs and thin layers of foam insulation. The cavity depth was $14 \mathrm{~cm}$. Each wall 
cavity was covered with a plastic mesh and then cellulose insulation was added by cutting a slot in the mesh at the top of the cavity. The cellulose was allowed to settle under its own weight. The measured cavity volume and estimated weight of cellulose insulation added to the cavities yielded an average density of $40.9 \mathrm{~kg} / \mathrm{m}^{3}$. The area surrounding the test cavities was filled with fiberglass insulation, to prevent convection loops in empty air spaces and minimize the thermal interaction with the neighboring test wall sections. The perimeter cavities are used for routing instrumentation cables and fiberglass batts were used to fill those perimeter cavities due to ease of installation.

\section{DATA ACQUISITION SYSTEM AND INSTRUMENTATION}

Figure 5 shows a typical instrumentation layout in the wall cavities. The wall contained vinyl siding and a weather barrier over OSB on the exterior side of the wall, which is exposed to the atmosphere (as seen on the south wall in Figure 3). The interior side is covered with a gypsum board. Each cavity contains a thermistor and RH sensor combination (T/RH sensor) on the OSB and gypsum surfaces facing the cavity, thermistor inside the cavity (mid-depth) and on the gypsum surface facing the room interior, and a heat flux transducers on the gypsum surface facing the cavity. Within each cavity, these sensors are located approximately in a line along both the vertical and horizontal midpoints of the cavity. In addition, a single thermistor is attached to the wall exterior (between OSB and exterior siding) and a T/RH sensor combination on the OSB surface facing the exterior, which are not shown in Figure 5. The T/RH sensors are indicated by the white packets seen in Figure 5.

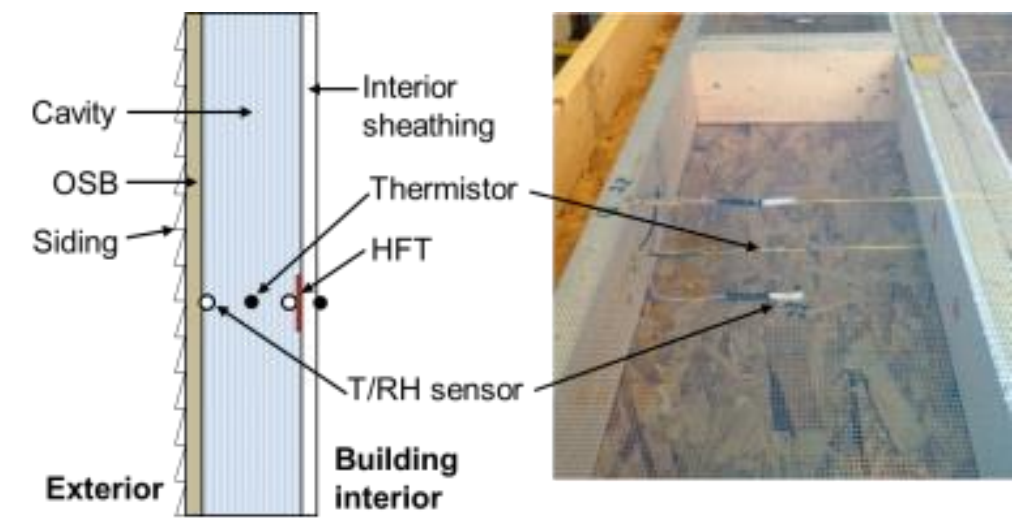

Figure 5. Sensor placement in test wall cavities.

The HFTs were calibrated using a heat flow meter apparatus (HFMA) while sandwiched by insulation and regular gypsum board. The HFMA is used for thermal transmission property measurements following ASTM Test Method C518 [ASTM, 2010] and is accurate within 1\%. The HFMA consists of two independently temperature-controlled plates, both of which are equipped with heat flow sensors. The calibration constants of the HFTs used in the Charleston test walls were obtained by correlating the measured heat flows of the HFMA to the HFT voltage outputs.

In addition to the sensors attached to the test wall, the NET facility includes sensors and instruments to monitor the local weather conditions, including temperature, humidity, solar irradiance, wind conditions, etc. These sensors are controlled and monitored by Campbell Scientific (CSI) CR10X dataloggers and multiplexers (http://www.campbellsci.com/cr10x). Each sensor is scanned at five minute intervals and the data are then averaged and stored at hourly intervals. The data are downloaded on a weekly basis at ORNL using a dedicated computer and modem. Table 2 provides the sensor 
specifications.

Table 2. Installed sensor accuracy.

\begin{tabular}{|l|c|c|c|c|}
\hline \multicolumn{1}{|c|}{ Sensor } & Accuracy & Sensitivity & Repeatability & Supply Voltage \\
\hline $\begin{array}{l}\text { Fenwall Uni-curve 10K ohm } \\
\text { thermistor }\end{array}$ & $\pm 0.2 \%$ & - & $\pm 0.2 \%$ & $2.5 \mathrm{Vdc}$ \\
\hline $\begin{array}{l}\text { Honeywell Hy-Cal Humidity } \\
\text { Sensor HIH-4000 Series }\end{array}$ & $\pm 3.5 \%$ & - & $\pm 0.5 \%$ & $5 \mathrm{Vdc}$ \\
\hline $\begin{array}{l}\text { Heat Flux Transducer (Concept } \\
\text { Engineering Model F-002-4) }\end{array}$ & $\pm 5 \%$ & $\begin{array}{c}\left(5.7 \mathrm{~W} / \mathrm{m}^{2}\right) / \mathrm{mV} / \\
{\left[\left(1.8 \mathrm{Btu} / \mathrm{hr}-\mathrm{ft}^{2}\right) / \mathrm{mV}\right]}\end{array}$ & - & - \\
\hline Outdoor RH (Vaisala CS500) & $\pm 3 \%$ & - & - & $12 \mathrm{Vdc}$ \\
\hline $\begin{array}{l}\text { Wind Speed (R. M. Young } \\
\text { Model 05305 Wind Monitor) }\end{array}$ & $\pm 0.4 \%$ & - & - & - \\
\hline $\begin{array}{l}\text { Wind Direction (R. M. Young } \\
\text { Model 05305 Wind Monitor) }\end{array}$ & $\pm 3 \circ$ & - & - & $12 \mathrm{Vdc}$ \\
\hline $\begin{array}{l}\text { Rainfall (Texas Electronics } \\
\text { Model TE525) }\end{array}$ & $\pm 1 \% @ 1 \% / \mathrm{hr}$ & - & - & - \\
\hline $\begin{array}{l}\text { Solar pyranometer, vertical (LI- } \\
\text { Cor LI200X }\end{array}$ & $\pm 3 \%$ & $0.2 \cdot \mathrm{kW} \cdot \mathrm{m}^{-2} \cdot \mathrm{mV}^{-1}$ & - & - \\
\hline $\begin{array}{l}\text { Solar pyranometer, horizontal } \\
\text { (Kipp \& Zonen SP-Lite }\end{array}$ & $\pm 3 \%$ & $10 \mu \mathrm{V} \cdot \mathrm{W}^{-1} \cdot \mathrm{m}^{-2}$ & - & $12 \mathrm{Vdc}$ \\
\hline $\begin{array}{l}\text { Campbell Sci CR10X w/32 } \\
\text { Channel multiplexer }\end{array}$ & $\begin{array}{c} \pm 0.1 \% \text { of } \\
\mathrm{FSR} * *\end{array}$ & - & - & - \\
\hline
\end{tabular}

*MC - Moisture content, **FSR - Full scale reading

\section{RESULTS AND DISCUSSION}

\subsection{FIELD DATA ANALYSIS}

This section describes the temperature and heat flux data from the test walls to examine the behavior and impact of the PCM prototype wallboards. The data are compiled into weekly files containing hourlyaveraged data. The period covered in this section is July-December 2012, after the installation of the second test wall. This period is deemed sufficient for the weather-related evaluation of the PCM products as it includes summer, winter and shoulder (fall) months. The focus is on summer and winter periods, when the cooling and heating loads are at their peak.

\section{Temperature Distribution and PCM Behavior}

The temperature distributions in the different sections of the two test walls are shown in Figure 6 and Figure 7. The hourly-averaged temperature data are shown for a typical summer week (July 18-25). The temperatures are shown at the wall exterior, the OSB interior (facing the cavity), the cavity center, the wallboard exterior (facing the cavity) and the wallboard interior (facing the room). 


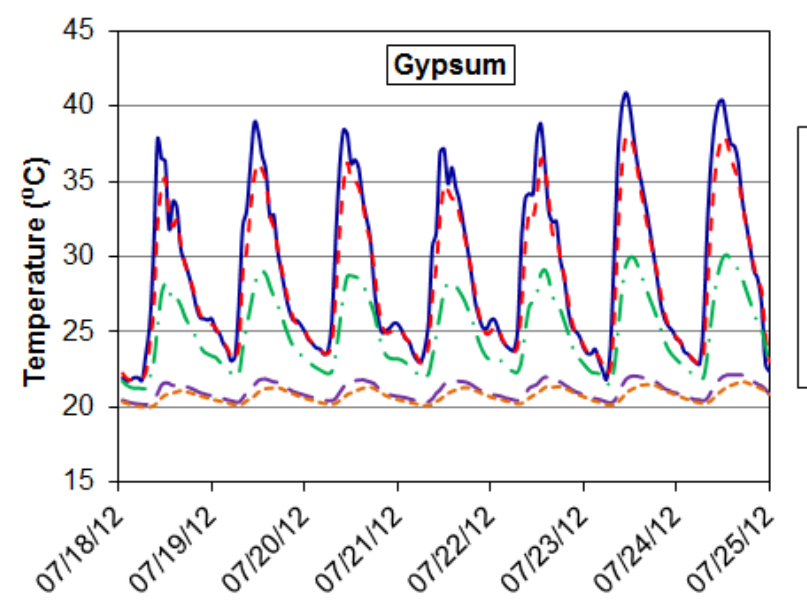

\section{-Wall Exterior \\ - - - OSB Interior \\ - - Cavity Center \\ - Wallboard Exterior \\ -----Wallboard Interior}
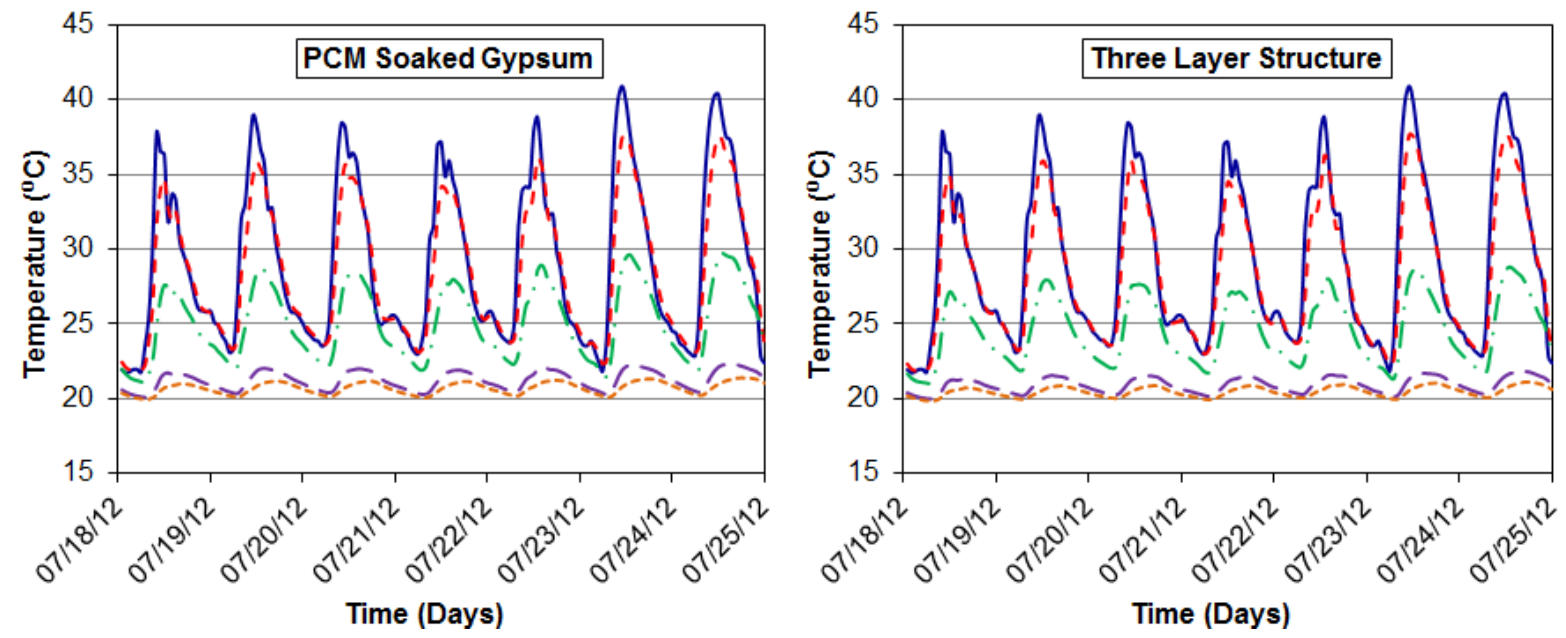

Figure 6. Temperature distribution in different sections of 'Test wall 1'.

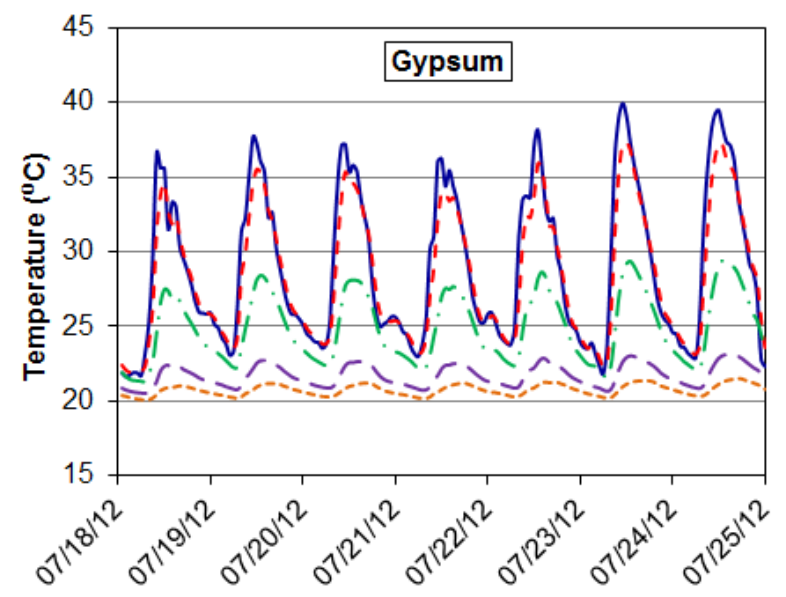

\section{—Wall Exterior \\ - - - OSB Interior \\ - - - Cavity Center \\ - - Wallboard Exterior \\ ----- Wallboard Interior}



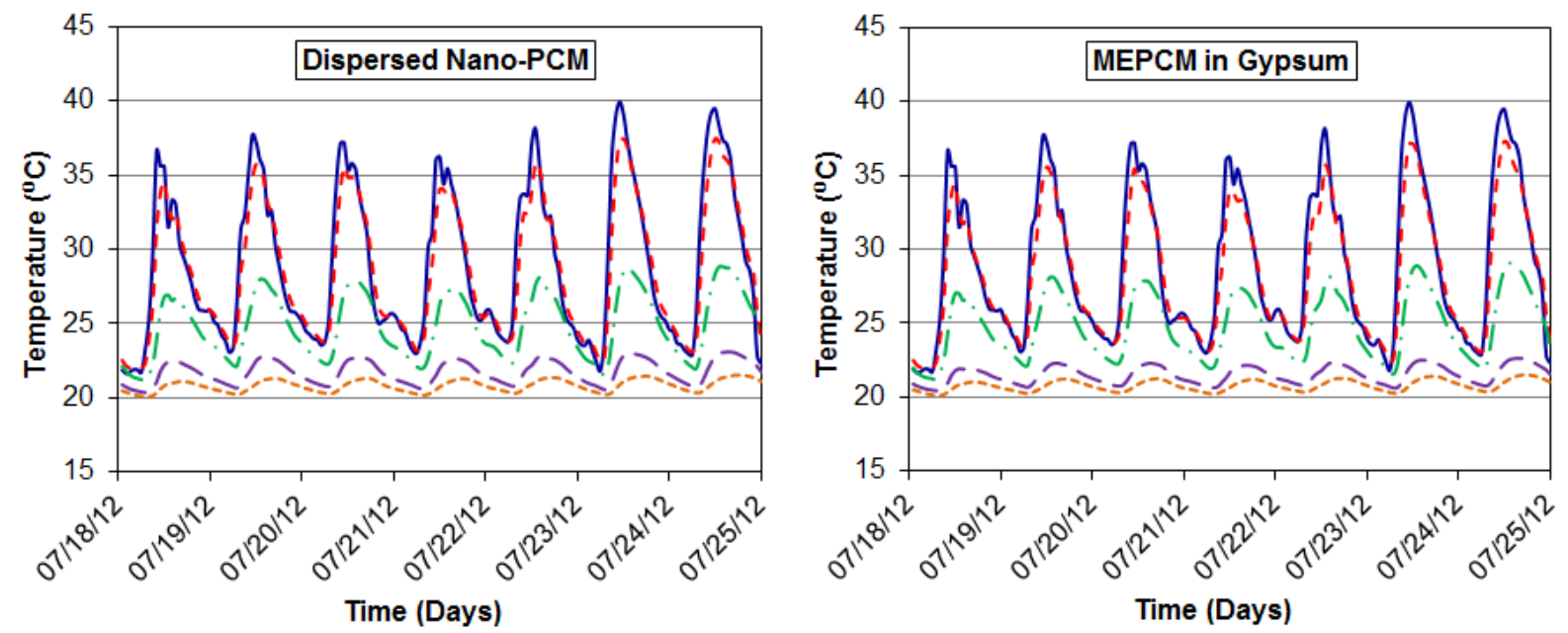

Figure 7. Temperature distribution in different sections of 'Test wall 2'.

The room interior was maintained at about $20-22^{\circ} \mathrm{C}$ during the monitoring period. A clear trend is seen in the temperatures from the exterior to the interior. Some differences are seen in the cavity center and the wallboard exterior between the different test walls and the test sections. However, these differences are fairly insignificant and do not reveal much about the behavior and impact of the PCMs in the different wallboards. To further examine the PCM behavior, the wallboard exterior and interior temperatures are shown in Figure 8, along with the corresponding melting and freezing onset temperatures. The data shown in Figure 8 have been compiled from the weekly data files from July 11 to December 26, 2012.
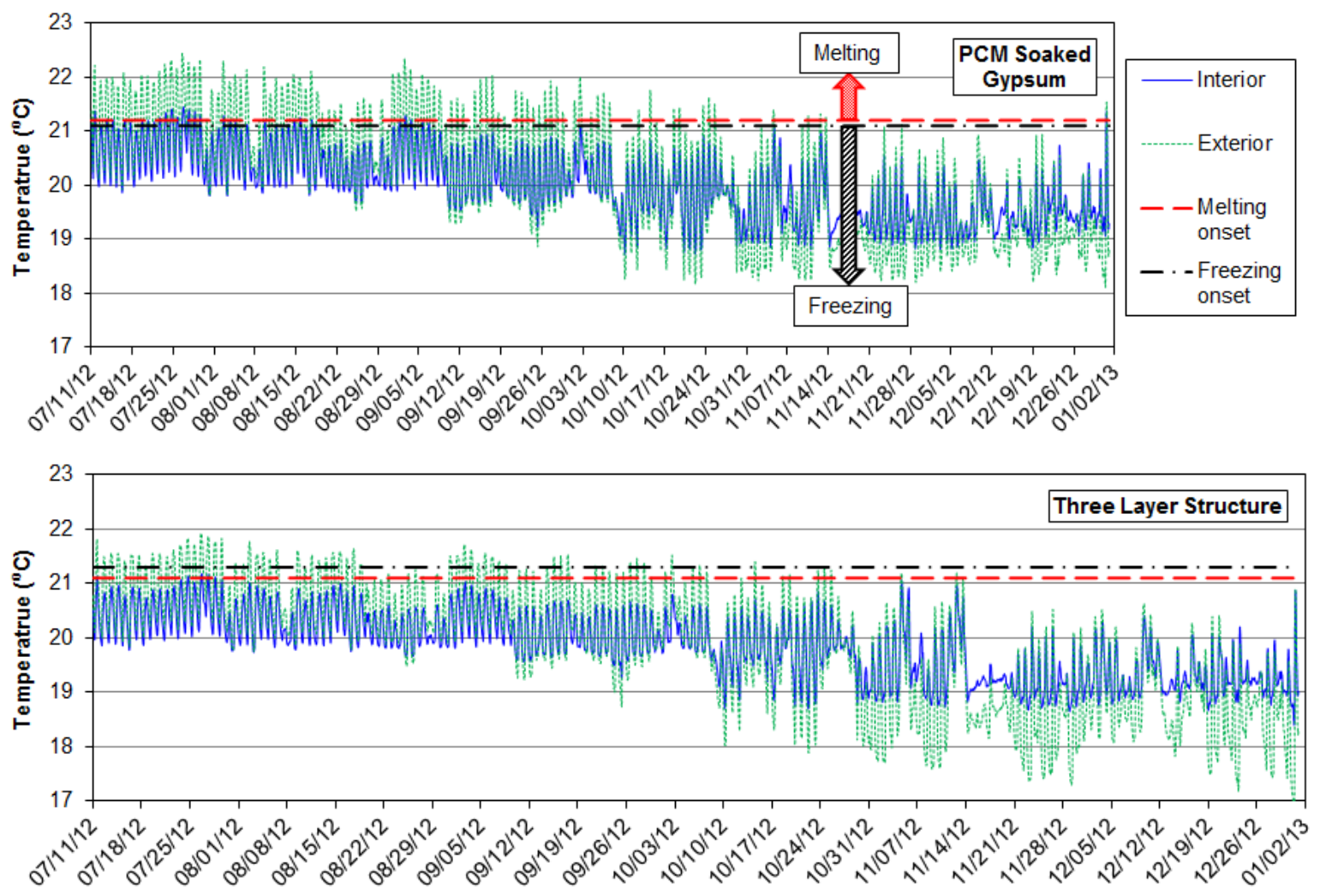

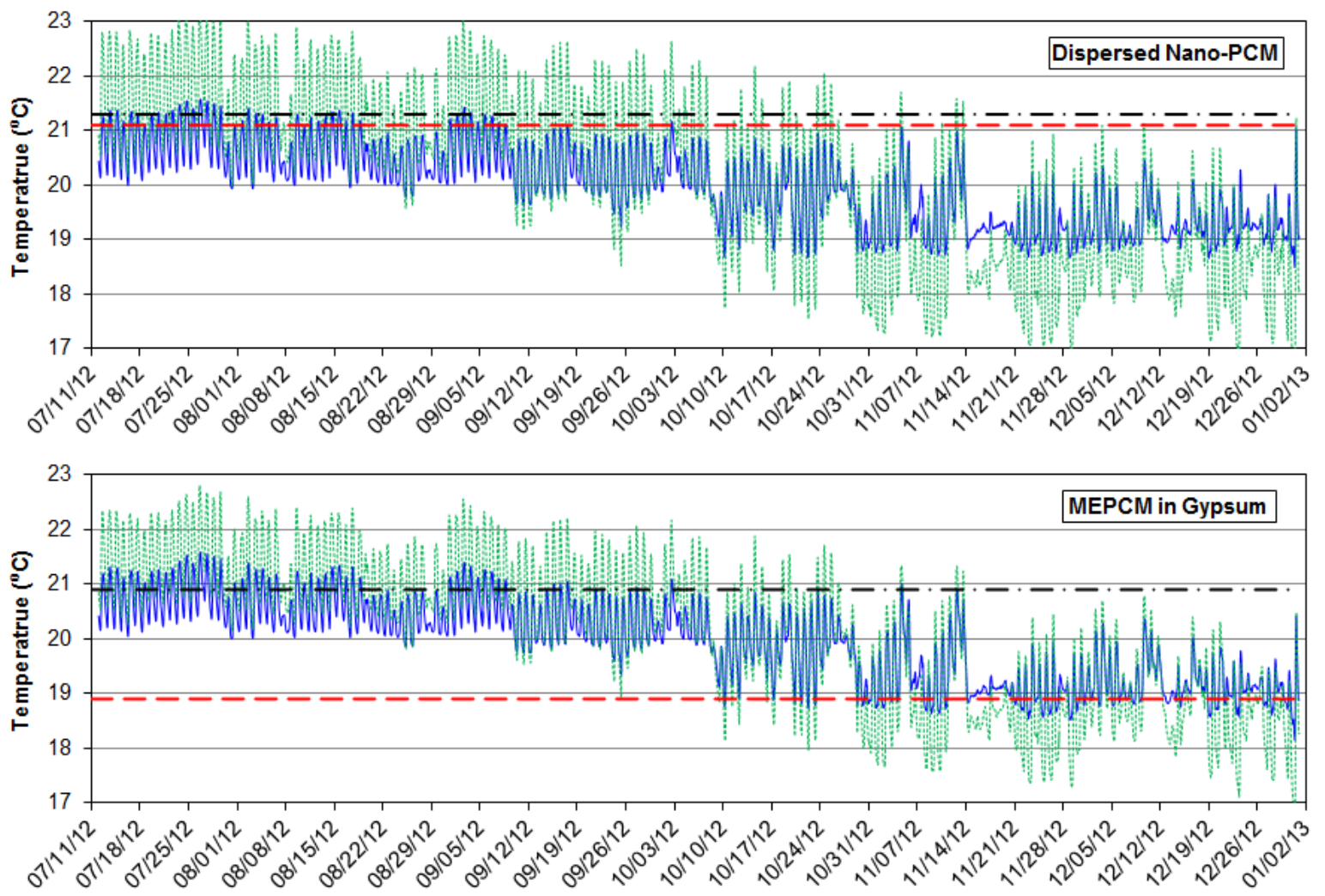

Figure 8. Comparison of PCM-enhanced wallboard interior and exterior temperatures with their respective phase change onset temperatures.

For maximum benefit from a PCM, it needs to melt and freeze on a diurnal basis, i.e. its temperature should rise above its melting point and fall below its freezing point on a daily basis. The hourly variations of the exterior and interior surface temperatures compared to the phase change onset temperatures can provide information about the effectiveness of the PCM prototype wallboards. The first plot in Figure 8 shows the behavior of the 'PCM Soaked Gypsum' wallboard. The exterior temperatures cycled above the melting onset temperature and below the freezing onset temperature almost every day during the summer months (July-September), and periodically in October, indicating frequent phase change activity near the surface of the wallboard facing the cavity. The interior wallboard temperatures, however, remained predominantly below the melting onset temperature during this time. From November onwards, the wallboard temperatures stayed predominantly below the melting onset temperature, and the PCM can be expected to have been frozen during this time.

The second plot shows the behavior of the 'Three Layer Structure' wallboard. The interior wallboard temperature remained below the melting point at all times. The exterior wallboard temperature cycled above and below the phase change temperatures from July till early-October, but remained below the melting point after that. The 'Dispersed Nano-PCM' had similar melting and freezing onset temperatures as the 'Three Layer Structure' wallboard. The diurnal exterior and interior temperatures oscillations were greater, so that the exterior temperatures rose above and below the melting and freezing onset temperatures from July through early-November. Even the interior temperatures rose above the melting point several times during July-September. 
The fourth plot shows the temperatures of the 'MEPCM in Gypsum' wallboard. This product has the lowest melting onset temperatures of all the wallboards, with the result that both exterior and interior wallboard temperatures were predominantly above the melting point. The wallboard temperatures cycled above and below the freezing onset temperature on a daily basis from July till early-October, less frequently from October to mid-November, and remained below the freezing point after that. Thus, unlike the other PCM products, the 'MEPCM in Gypsum' wallboard can be expected to have undergone at least partial melting and freezing even during the winter period.

In summary, the temperature data indicate that the first three wallboards underwent at least partial melting and freezing between July and mid-November, especially near the exterior surface facing the wall cavities, and remained predominantly frozen thereafter. The 'MEPCM in Gypsum' wallboard, however, showed phase change activity throughout the evaluation period.

\section{Heat Flux Variation}

In this section, data from the HFTs installed in the test cavities are shown and described. It should be noted that the HFTs measuring the heat flux were installed on the exterior surface of the wallboards (facing the cavity). From a space conditioning perspective, the heat flux that actually enters the conditioned area is of primary interest. In the test sections, since the PCMs are contained in the wallboards, the locations of the HFTs is not ideal as they do not fully capture the impact of the melting and freezing of PCMs on the heating and cooling loads in the conditioned area. The HFTs only capture the heat flow between the wallboard and the cavity, which may be different from the heat flow at the wallboard interior due to the latent heat storage/release within the wallboards.

Figure 9 and Figure 10 show the hourly heat fluxes during a summer and winter week, respectively, through the different test sections in the two test walls, 'Test wall 1' and 'Test wall 2'. The control gypsum test sections are shown for comparison. Also shown is the hourly solar irradiance on the test wall exteriors. As expected, the day time heat fluxes show a strong correlation with the solar irradiance.

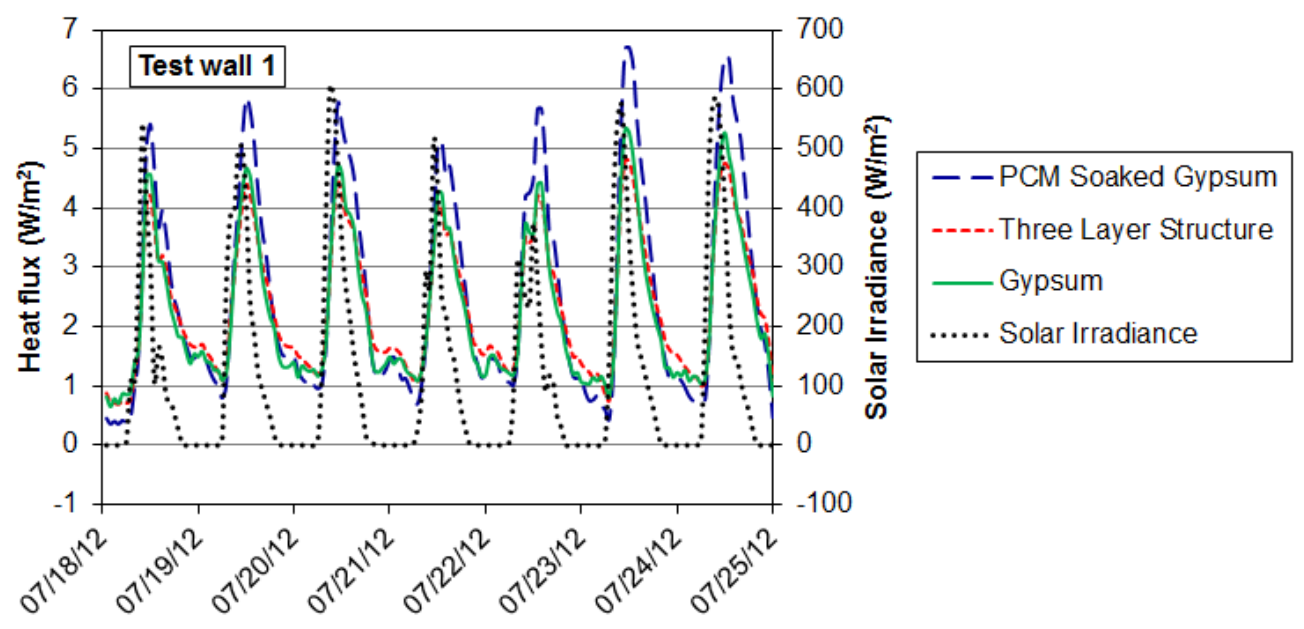




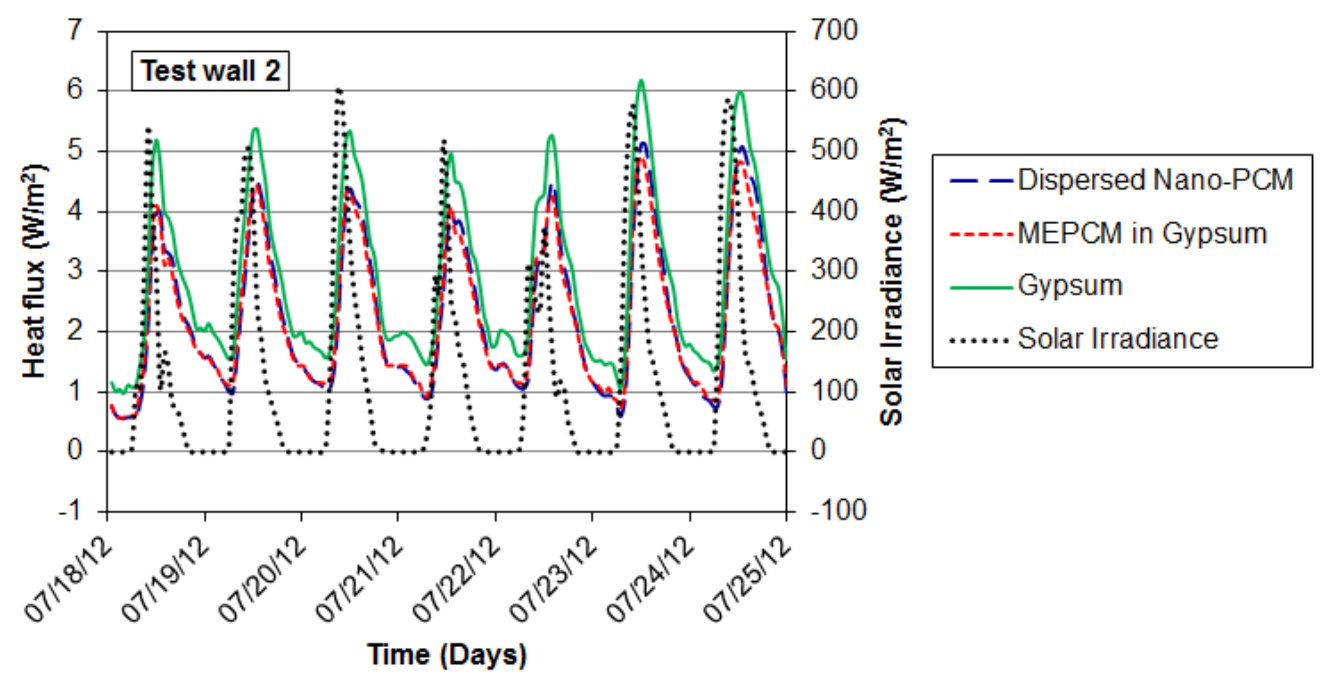

Figure 9. Summer heat flux variation and solar irradiance.

In Figure 9, the first plot shows the test sections in Test wall 1. The behavior of the 'Three Layer Structure' wallboard is similar to the control gypsum section, but the peak day time heat gains in the 'PCM Soaked Gypsum' section are higher, by up to 30\% compared to the control. Both PCM wallboards in Test wall 2 reduced the peak day time heat gains by about $20 \%$ compared to the gypsum section, which is beneficial in reducing the cooling loads on the conditioned space.

Figure 10 shows the heat flux variations during a winter week. There was very little heat gain measured by the HFTs during this week, with substantial heat losses, especially during the night. The daytime peaks were similar between the PCM wallboards and their respective control sections. In 'Test wall 1', both PCM wallboard sections exhibited greater peak heat losses compared to the gypsum control; conversely, in 'Test wall 2', both PCM sections reduced the heat losses at night compared to the gypsum section.

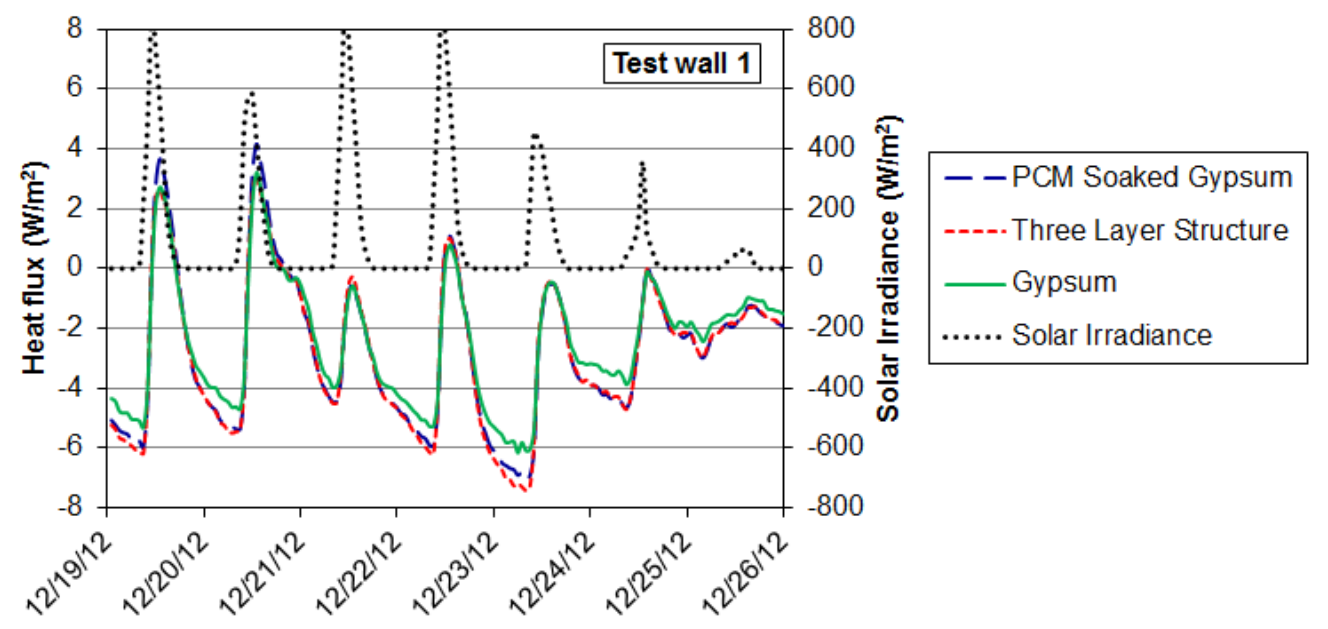




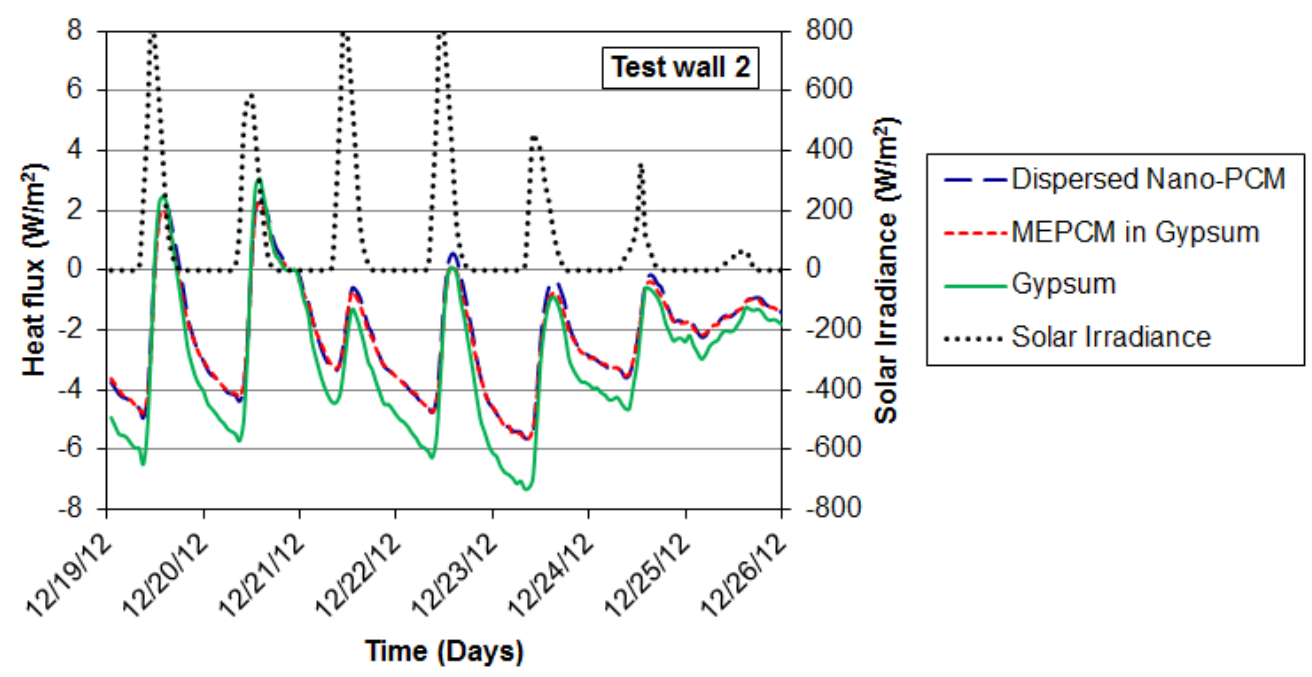

Figure 10. Winter heat flux variation and solar irradiance.

To further investigate the impact of the PCM-enhanced wallboards, the heat flux data though the different wall sections were integrated over 30-day winter and summer periods to determine the total heat gains and losses through the different sections. The integration was performed using the trapezoidal rule:

$$
\text { Total Integrated Heat Flow, } Q\left[\frac{k J}{m^{2}}\right]=\sum_{n=0}^{m} 0.5 * \Delta X_{n} *\left(Y_{n}+Y_{n+1}\right)
$$

In above equation, $Y_{n}$ and $Y_{n+1}$ correspond to the heat flux during current and future time steps, $\Delta X_{n}$ is the time step (one hour in this case), and the subscript ' $\mathrm{m}$ ' denotes the final point in the series which varies depending on the summer or winter data sets. The positive and negative heat fluxes were integrated separately to determine the heat gains and losses for each section. The integrated or total heat gains and losses and the net heat transfer during summer and winter periods are shown in tables 3 and 4 . The net heat transfer for each period was obtained by integrating the positive and negative heat fluxes together. Also shown in the tables are the percent reductions compared to the respective gypsum control sections.

Using the general uncertainty analysis method described by Coleman and Steele [1989], the uncertainty $\left(U_{Q}\right)$ in the integrated heat flow $(\mathrm{Q})$ can be described by:

$$
U_{Q}^{2}=\left[\left(\frac{\partial Q}{\partial Y_{n}} U_{Y}\right)^{2}+\left(\frac{\partial Q}{\partial Y_{n+1}} U_{Y}\right)^{2}\right]^{1 / 2}
$$

Assuming a 5\% uncertainty $\left(U_{Y}\right)$ in the HFT measurements, the uncertainty of the integrated heat flows reported in tables 3 and 4 is $7.1 \%$.

30-day periods were chosen that represent typical summer and winter conditions to analyze the data. The 30-day summer period extended from July 13 to August 11, 2012 and the winter period was December 2-31, 2012. Table 3 lists the integrated heat flows from the first test wall, 'Test wall 1'. Clearly, both PCM wallboards did not perform as well as expected, allowing both higher heat gains during summer and higher heat losses during winter. Both PCM wallboards used in 'Test wall 2' performed better than the gypsum control (Table 4), with about 21-26\% reductions in heat gain and heat loss during the cooling and heating seasons, respectively. The 'Dispersed Nano-PCM' wallboard performed better than the wallboard with the commercially available MEPCM in reducing both heating 
and cooling loads.

Table 3. Heat flux statistics for Test wall 1

\begin{tabular}{|l|c|c|c|c|c|c|}
\hline & $\begin{array}{c}\text { Heat Gain } \\
\left(\mathbf{k J} / \mathbf{m}^{\mathbf{2}}\right)\end{array}$ & \% Reduction & $\begin{array}{c}\text { Heat Loss } \\
\left(\mathbf{k J} / \mathbf{m}^{\mathbf{2}}\right)\end{array}$ & \% Reduction & Net $\left(\mathbf{k J} / \mathbf{m}^{2}\right)$ & \% Reduction \\
\hline \multicolumn{7}{|c|}{ Summer 30-day period (Jul 13 - Aug 11, 2012) } \\
\hline PCM Soaked Gypsum & 5839.6 & -9.76 & -6.6 & & 5832.9 & -9.63 \\
\hline Three Layer Structure & 5459.5 & -2.61 & -0.7 & & 5458.8 & -2.60 \\
\hline Gypsum & 5320.4 & 0.0 & 5320.4 & \\
\hline \multicolumn{7}{|c|}{ Winter 30-day period (Dec 2 - Dec 31, 2012) } \\
\hline PCM Soaked Gypsum & 633.2 & -36.59 & -5727.3 & -17.12 & -5094.1 & -15.08 \\
\hline Three Layer Structure & 483.9 & -4.38 & -5780.5 & -18.21 & -5296.6 & -19.66 \\
\hline Gypsum & 463.5 & & -4890.1 & & -4426.5 & \\
\hline
\end{tabular}

Table 4. Heat flux statistics for Test wall 2

\begin{tabular}{|l|c|c|c|c|c|c|}
\hline & $\begin{array}{c}\text { Heat Gain } \\
\left(\mathbf{k J} / \mathbf{m}^{\mathbf{2}}\right)\end{array}$ & \% Reduction & $\begin{array}{c}\text { Heat Loss } \\
\left(\mathbf{k J} / \mathbf{m}^{2}\right)\end{array}$ & \% Reduction & Net $\left(\mathbf{k J} / \mathbf{m}^{2}\right)$ & \% Reduction \\
\hline \multicolumn{7}{|c|}{ Summer 30-day period (Jul 13 - Aug 11, 2012) } \\
\hline Dispersed Nano-PCM & 5263.0 & 22.86 & -0.2 & & 5262.8 & 22.86 \\
\hline MEPCM in Gypsum & 5336.2 & 21.78 & 0.0 & & 5336.2 & 21.78 \\
\hline Gypsum & 6822.3 & 0.0 & & 6822.3 & \\
\hline \multicolumn{7}{|c|}{ Winter 30-day period (Dec 2 - Dec 31, 2012) } \\
\hline Dispersed Nano-PCM & 453.9 & 5.65 & -4333.0 & 25.88 & -3879.1 & 27.70 \\
\hline MEPCM in Gypsum & 406.9 & 15.42 & -4403.5 & 24.68 & -3996.6 & 25.50 \\
\hline Gypsum & 481.0 & & -5846.0 & & -5365.0 & \\
\hline
\end{tabular}

It is again noted that, the heat fluxes shown in Figure 9 and Figure 10 and the integrated heat flows listed in Tables 4 and 5, are not truly representative of the heat addition to or loss from the conditioned space, due to the location of the HFTs. Further, the positive daytime heat flows measured in the PCM sections during summer may be augmented if the PCM was melting and absorbing heat at the cavitywallboard interface. Conversely, the night time losses may include the heat released at the cavitywallboard interface due to the freezing of the PCM.

\section{Additional Measurement Uncertainties}

An additional source of errors or uncertainties in the measurements were potential air gaps in the cavities due to settling of cellulose under its own weight. Due to concerns regarding the settling of cellulose, both test walls were inspected at the end of the field-test period. The internal wall boards were removed to visually inspect the wall cavities. Figure 11 and Figure 12 show sample images from Test wall 1 ('wall 11') and Test wall 2 ('wall 9'), respectively. The numbers 9 and 11 were internally assigned to identify different test sections at the Charleston NET facility.

The lower right section of Test wall 1 ('Gypsum') clearly shows evidence of air gaps resulting from settling of cellulose at the top of the cavity and near the sensors (Figure 11), which were installed using strings stretched across the cavity width. Similar air gaps were also observed in two other sections of Test wall 1 ('PCM Soaked Gypsum' and 'Three Layer Structure'). 
In Test wall 2, minor air gaps were observed near the sensors in the gypsum section (Figure 12) and the 'MEPCM in Gypsum' section, but not in the 'Dispersed Nano-PCM' section. No gaps were observed at the top of the cavities in Test wall 2.

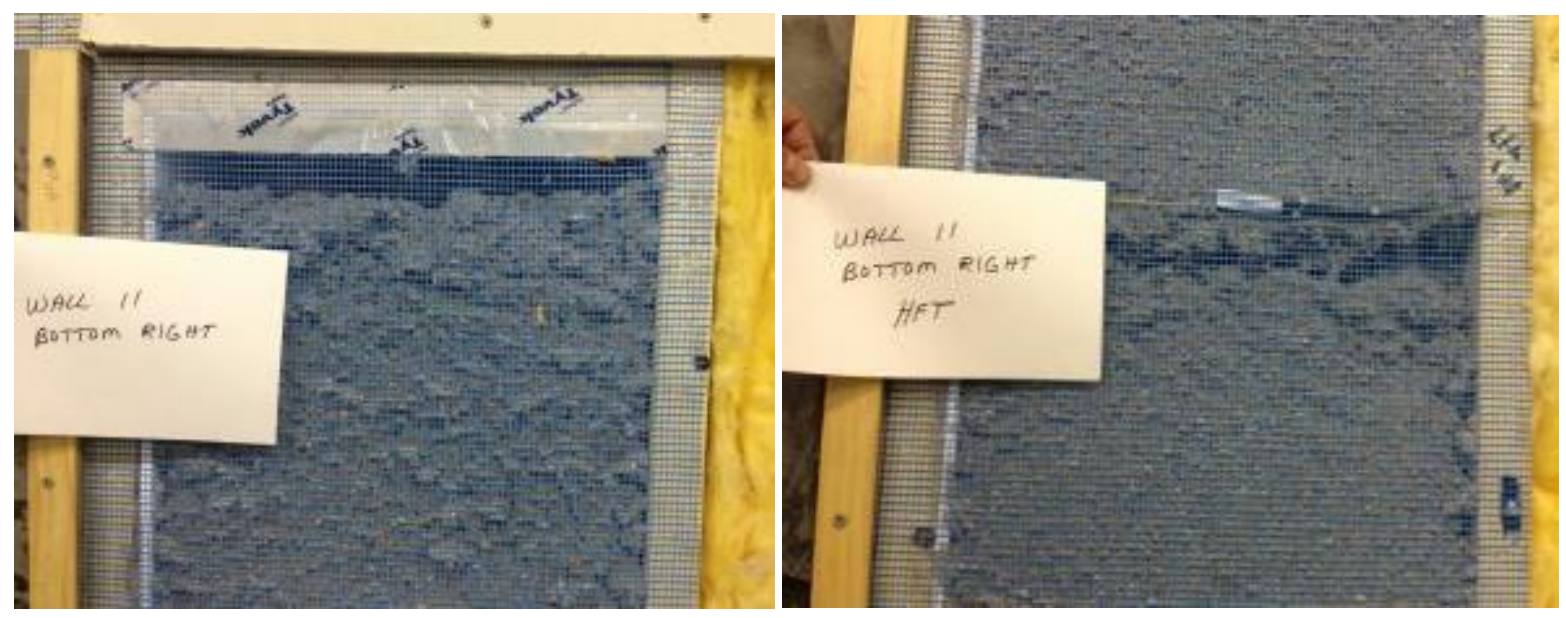

Figure 11. Gaps in wall cavities due to settling of cellulose, in the gypsum section of 'Test wall 1'.

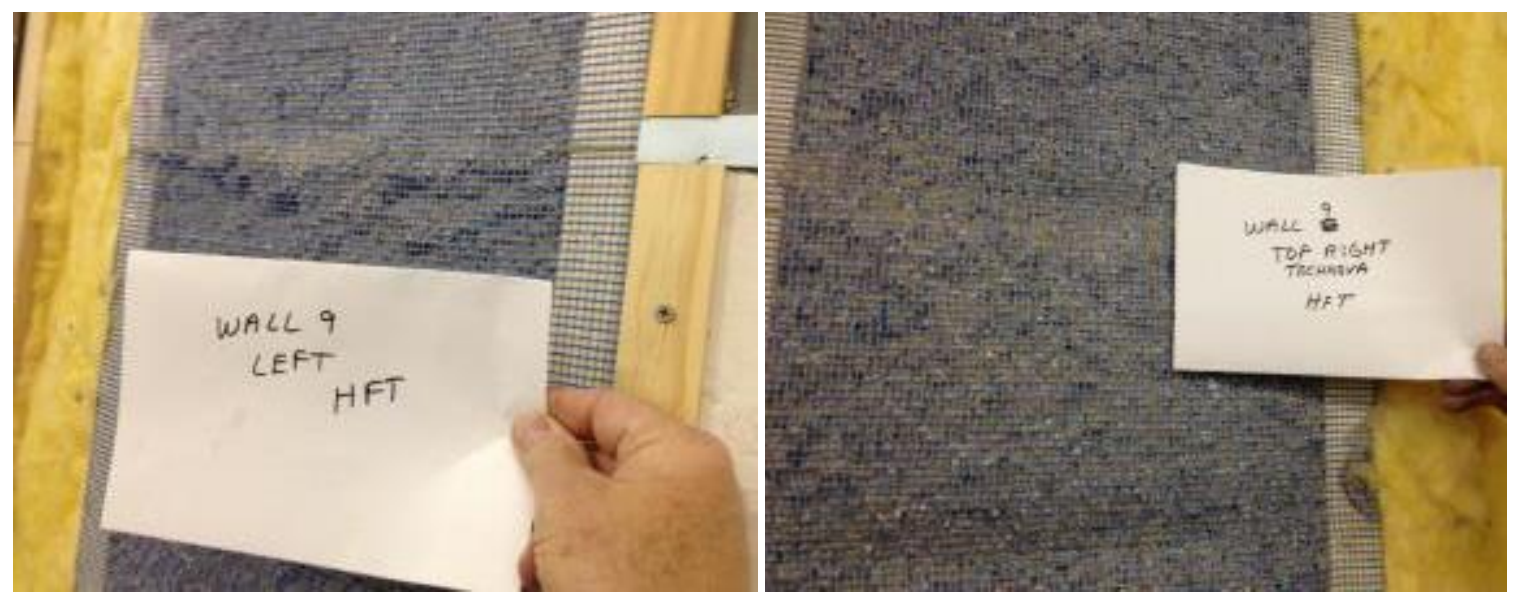

Figure 12. Gypsum (left) and 'Dispersed Nano-PCM' (right) sections from 'Test wall 2'; the gypsum section exhibited air gaps near the sensors.

\subsection{NUMERICAL MODELING}

To fully ascertain the impact of the PCM wallboards on the wall-generated heating and cooling loads, numerical modeling is necessary. 2-dimensional (2D) finite element models were created using COMSOL Multiphysics (version 4.3a) ${ }^{3}$. Based on the heat flow data, the 'Dispersed Nano-PCM' and 'MEPCM in Gypsum' wallboards were chosen for further investigation, along the gypsum control section of Test wall 2.

\footnotetext{
${ }^{3}$ http://www.comsol.com/
} 


\section{Material Properties}

Table 5 lists the material properties used in the numerical model. These values were obtained from literature or through measurements.

Table 5. Material properties for numerical modeling

\begin{tabular}{|c|c|c|c|}
\hline & $\begin{array}{c}\text { Density ( }(\rho) \\
\left(\mathrm{kg} / \mathrm{m}^{3}\right)\end{array}$ & $\begin{array}{c}\text { Thermal } \\
\text { conductivity }(\mathbf{k}) \\
(\mathbf{W} / \mathbf{m} / \mathbf{K})\end{array}$ & $\begin{array}{c}\text { Specific } \\
\text { heat }\left(c_{\mathrm{p}}\right) \\
(\mathbf{k J} / \mathbf{k g} / \mathbf{K})\end{array}$ \\
\hline Cellulose & 40.8 & 0.042 & 1.424 \\
\hline Wood stud & 576.7 & 0.144 & 1.633 \\
\hline OSB & 640.0 & 0.130 & 1.410 \\
\hline Foam (EPS) & 24.0 & 0.037 & 1.214 \\
\hline Gypsum & 549.5 & 0.153 & 1.089 \\
\hline \multirow{2}{*}{ Dispersed Nano-PCM } & \multirow{2}{*}{658.5} & $0.410(\mathrm{~s})$ & $2.312(\mathrm{~s})$ \\
\hline & & $0.427(1)$ & $2.236(1)$ \\
\hline \multirow{2}{*}{ MEPCM in Gypsum } & \multirow{2}{*}{579.4} & $0.281(\mathrm{~s})$ & $2.125(\mathrm{~s})$ \\
\hline & & $0.281(1)$ & $1.895(\mathrm{l})$ \\
\hline
\end{tabular}

The specific heats of the PCM wallboards in the fully frozen and fully molten states of the PCMs were obtained from the DSC data. However, the effect of phase transition, or latent heat of melting/freezing, needs to be included in the specific heat $\left(c_{p}\right)$ of the PCM wallboards. The $c_{p}$ during phase transition can be calculated directly from the DSC data, however the sharp changes in $c_{p}$ as function of temperature result in a lack of convergence in the numerical solution [Groulx et al., 2012]. To overcome this issue, following Biwole et al. [2013], a modified cumulative enthalpy $\left(h_{m o d}\right)$ was defined, as shown in eq. 3. $B(T)$ is the melt fraction, as defined in eq. 4 , and $D(T)$ is a Gaussian function (eq. 5), with an integral of 1 .

$$
\begin{aligned}
& h_{\text {mod }}(T)=\int\left[c_{p s}+\left(c_{p l}-c_{p s}\right) B(T)+L_{f} D(T)\right] d T \\
& B(T)=\left\{\begin{array}{c}
0, h<h_{s} \\
\left(h-h_{s}\right) / L_{f}, h_{s} \leq h \leq h_{l} \\
1, h>h_{l}
\end{array}\right. \\
& D(T)=e^{\frac{-\left(T-T_{m}\right)^{2}}{\Delta T^{2}}} / \sqrt{\pi \Delta T^{2}}
\end{aligned}
$$

' $c_{p s}$ ' and ' $c_{p l}$ ' are the specific heats of the fully frozen and fully molten PCMs, obtained from the DSC data. ' $T_{m}$ ' is the mid-point and ' $\Delta T$ ' the half-width of the phase change temperature range (listed in Table 1). ' $h_{s}$ ' and ' $h$ ' are the cumulative enthalpies at the onset and end of the melting process and ' $L_{f}$ ' is the latent heat of melting/freezing, also obtained from the DSC data.

Finally, the specific heat of the PCM wallboards was defined as,

$$
c_{p, \text { mod }}(T)=\frac{d h_{\text {mod }}}{d T}
$$

The thermal conductivity of the PCM wall boards was defined as, 


$$
k(T)=k_{S}+\left(k_{l}-k_{S}\right) B(T)
$$

' $k_{s}$ ' and ' $k$ ' are the thermal conductivities of the wallboards when the PCMs were fully frozen and fully molten, respectively, and were measured using the HFMA following ASTM C518 [2010].

Figure 13 shows a comparison of the cumulative enthalpy, h (DSC), calculated using the DSC data, to the cumulative enthalpy, h_mod $(\mathrm{D}(\mathrm{T}))$, obtained using eq. 3. Since the cumulative enthalpies $(h)$ were only used to calculate $c_{p}$ for the models, and since $c_{p}$ is only dependent on the slope of $h(T), h$ was chosen to be zero at arbitrary temperatures below the phase change temperature range of the PCM wallboards and calculated up to temperatures higher than the phase change temperature range. Cumulative enthalpy from the DSC data and the modified cumulative enthalpy (from eq. 3) were within $10 \%$ of each other. Figure 13 also shows the melt fraction as a function of temperature for the PCM wallboards.

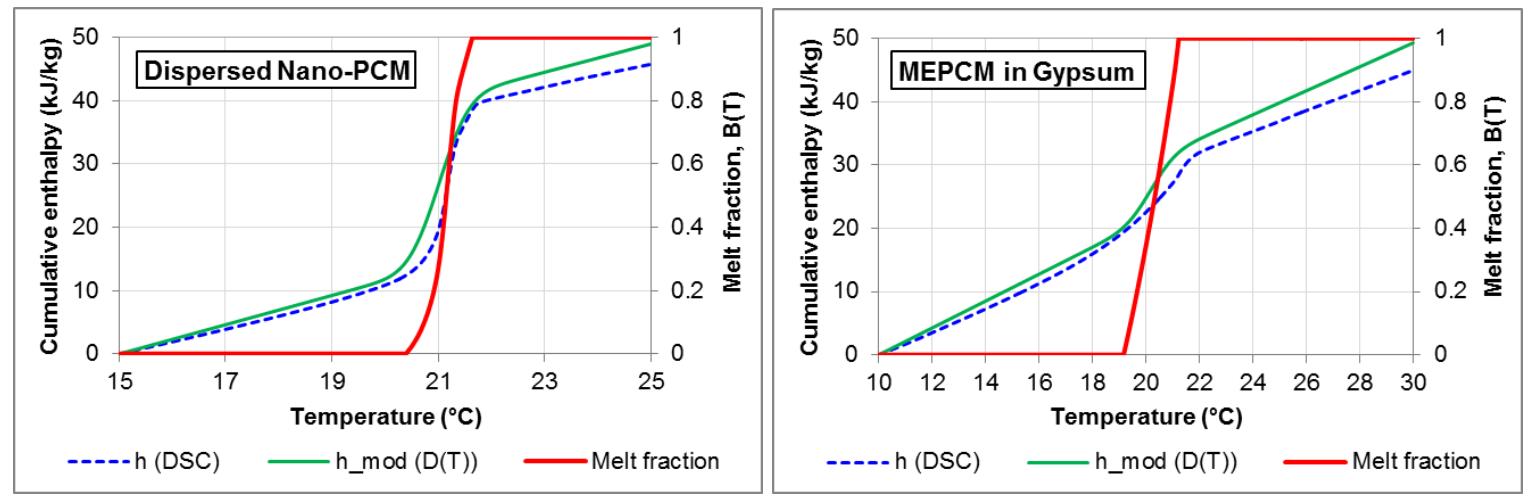

Figure 13. PCM wallboard cumulative enthalpies and melt fractions.

The cumulative enthalpies used in the above analysis were generated using the average of the heat gain/loss data from the melting and freezing DSC tests. In general, the phase change enthalpy is not an identical function of temperature for melting and freezing of PCMs. This phenomenon in PCMs is referred to as 'hysterisis' and it is particularly significant with certain types of PCM, for example inorganic PCMs. However, past research [Castellon, 2008] has shown that, at very slow heating and cooling rates $(\sim 0.1 \mathrm{C} / \mathrm{min})$, the hysteresis effect in paraffinic PCMs, such as the present nano-PCM, is negligible. In fact, the DSC data shown in Figure 1 and Figure 2 show that the phase change temperatures during cooling and heating are nearly identical. The location of the wallboards in the test wall exposes the PCM to very small $\left(\sim 2-3^{\circ} \mathrm{C}\right)$ diurnal temperature variations and, consequently, very slow heating/cooling rates. Thus, using averaged cumulative enthalpy as a function of temperature is deemed appropriate.

\section{Model Validation}

Before calculating the reduction in total wall-generated heating and cooling loads from the numerical models, they need to be validated against experimental data. For this purpose, 2D models of the actual test walls were created. Figure 14 shows the model geometry, which replicates a 2D cross-section of Test wall 2. The section shown corresponds to the vertical centerline of the PCM wallboard sections on the right side of Test wall 2 (Figure 4). The 2D wall section was divided into two cavities, divided by wood studs and foam insulation in the middle, with different internal wallboards for the top and bottom sections. A similar model geometry was created for the gypsum control section, with the internal gypsum wallboard spanning the entire height of the wall. The wall geometries were built using the actual 
dimensions of Test wall 2 in the Charleston facility.

The different components of modeled test wall section are shown in Figure 14. Figure 14 also shows the locations of 'thermistors' and 'HFTs' in the model geometry. These were locations within the model geometry where the simulation results were monitored and used for comparison with the experimental data. These locations were chosen to be as close as possible to the sensor locations in Test wall 2 (Figure 5). The 'thermistor' near the internal wallboard surface facing the cavity was offset. This is because the T/RH sensors in the actual test wall weren't attached to the exterior face of the internal wallboards, but were slightly inside the cavities once they were filled with cellulose insulation (Figure 15).

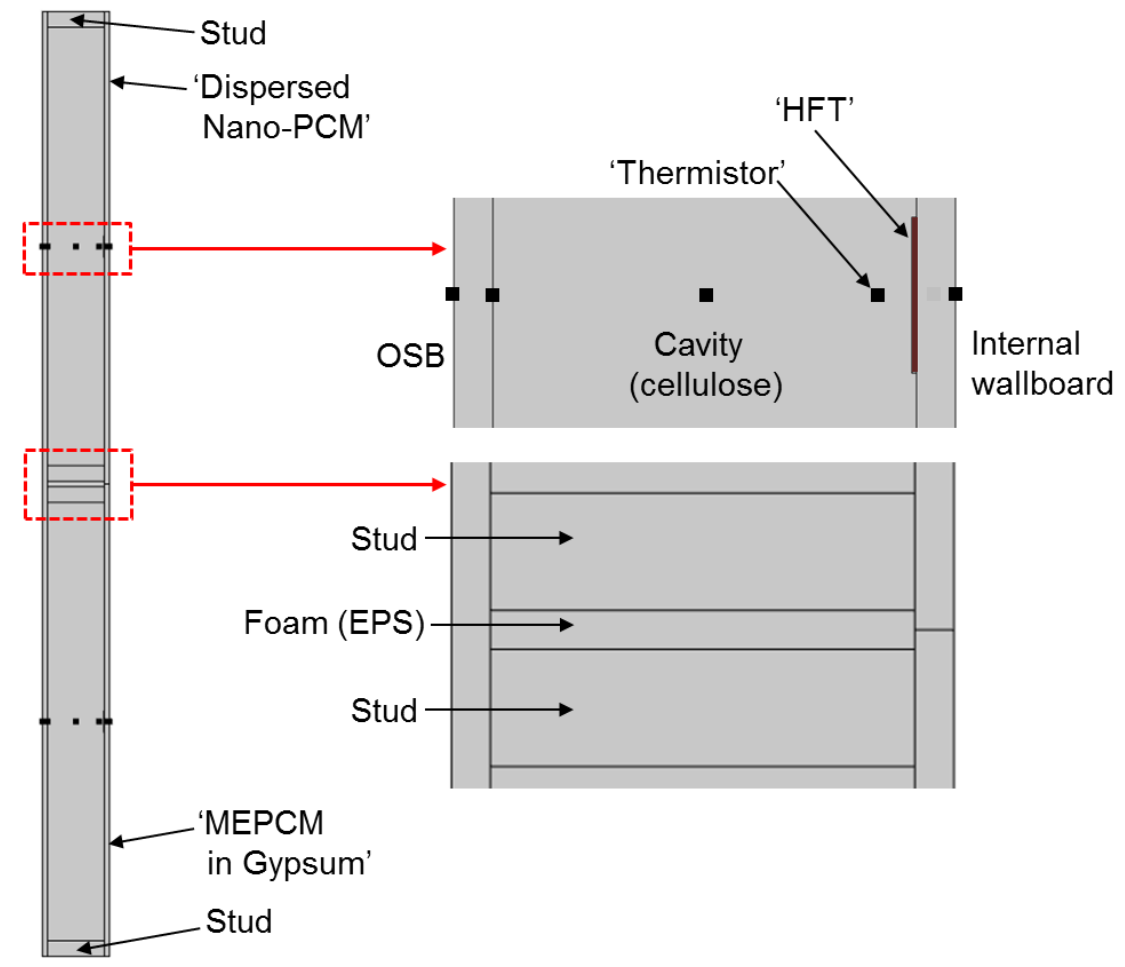

Figure 14. Numerical model geometry showing the wall sections containing the 'Dispersed Nano-PCM' (top) and 'MEPCM in Gypsum' (bottom) wallboards.

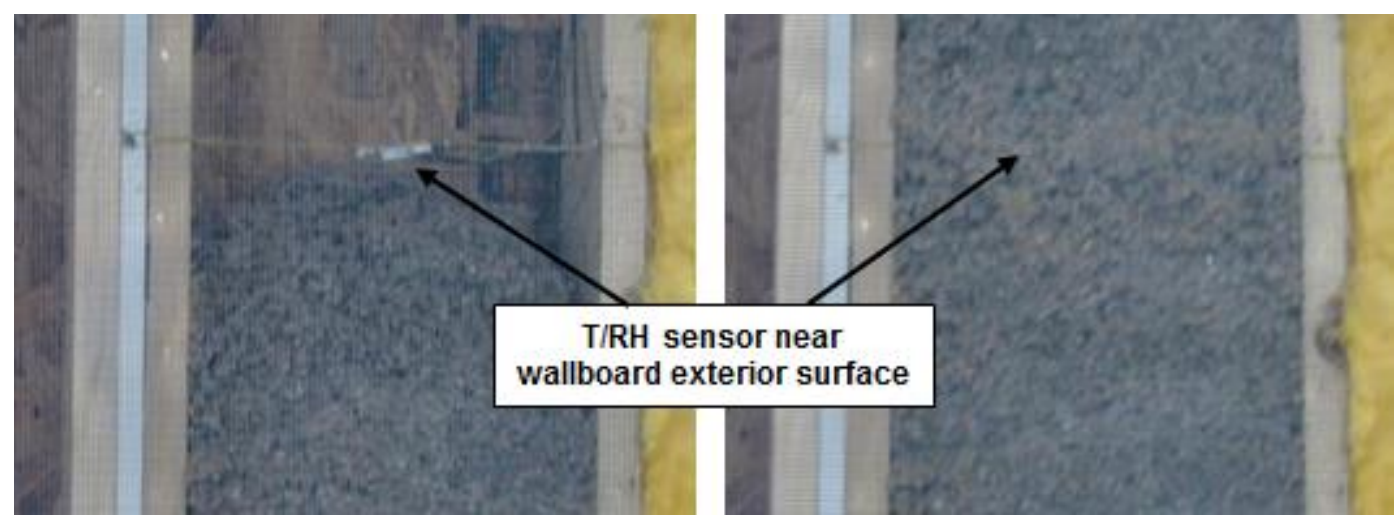

Figure 15. Location of the T/RH sensor near the exterior surface on an internal wallboard.

The model solved the following time-dependent energy equation, 


$$
\rho c_{p} \frac{\partial T}{\partial t}=-k \frac{\partial T}{\partial x}
$$

Exterior and interior wall surface temperatures from the experimental data were used as boundary conditions on the exterior and interior surfaces. Insulated, or adiabatic, boundary conditions were assumed at the top and bottom of the wall model, which is appropriate since the area surrounding the cavities was filled with fiberglass insulation (Figure 4).

In Figure 16 and Figure 17, the model calculations are compared to the temperature data from Test wall 2 during four summer and four winter days, respectively. '[C]' indicates the model calculations using COMSOL. The temperature locations are as shown in Figure 5 and Figure 14. Overall, there is excellent agreement between model calculations and experimental data. The only location where major differences were observed was the 'Wallboard Exterior' in the 'Gypsum' section. These differences can partly be explained by the air gaps observed near the sensors in the 'Gypsum' section of Test wall 2 (Figure 12).
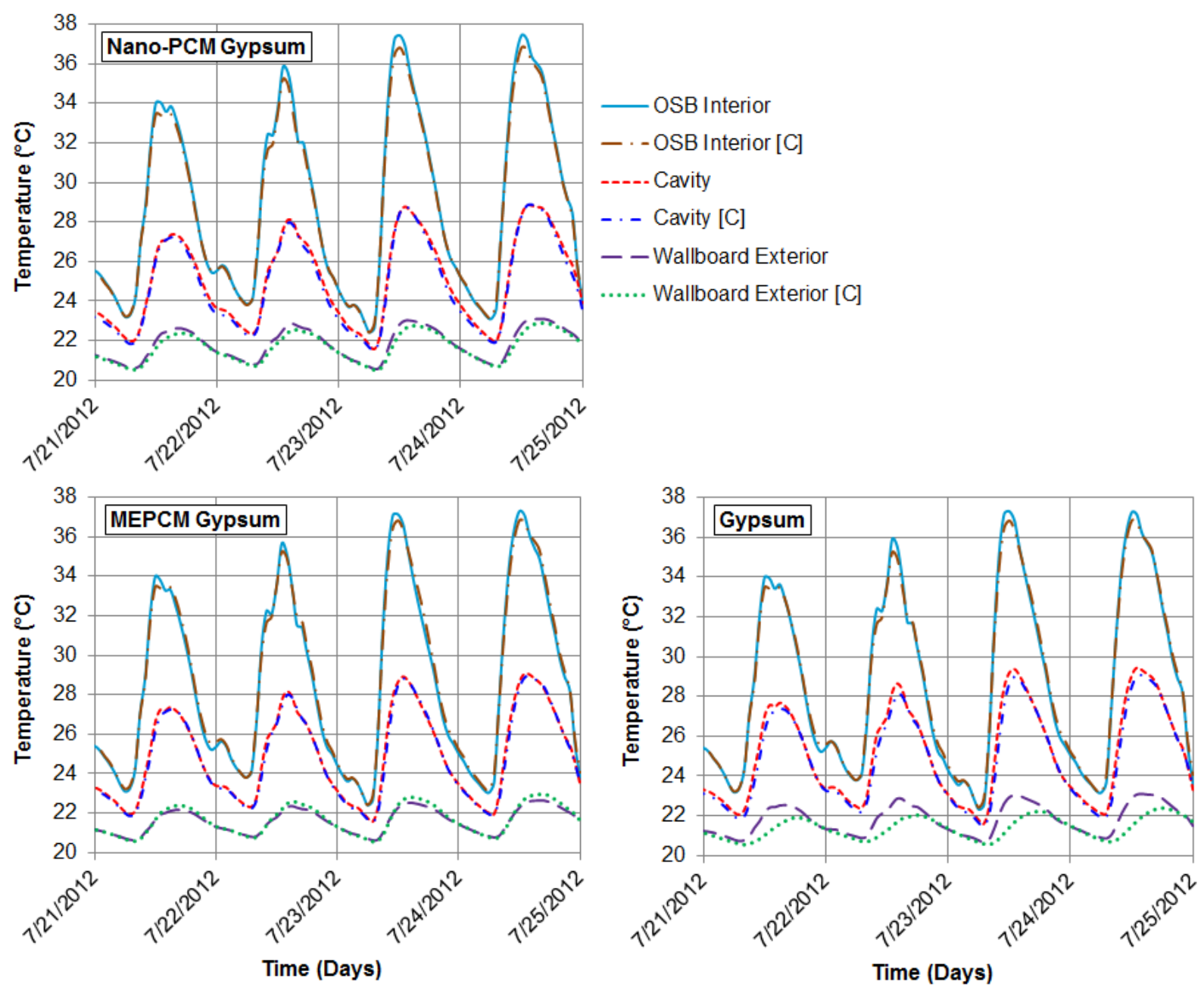

Figure 16. Comparison of model calculations with temperature data (summer). 


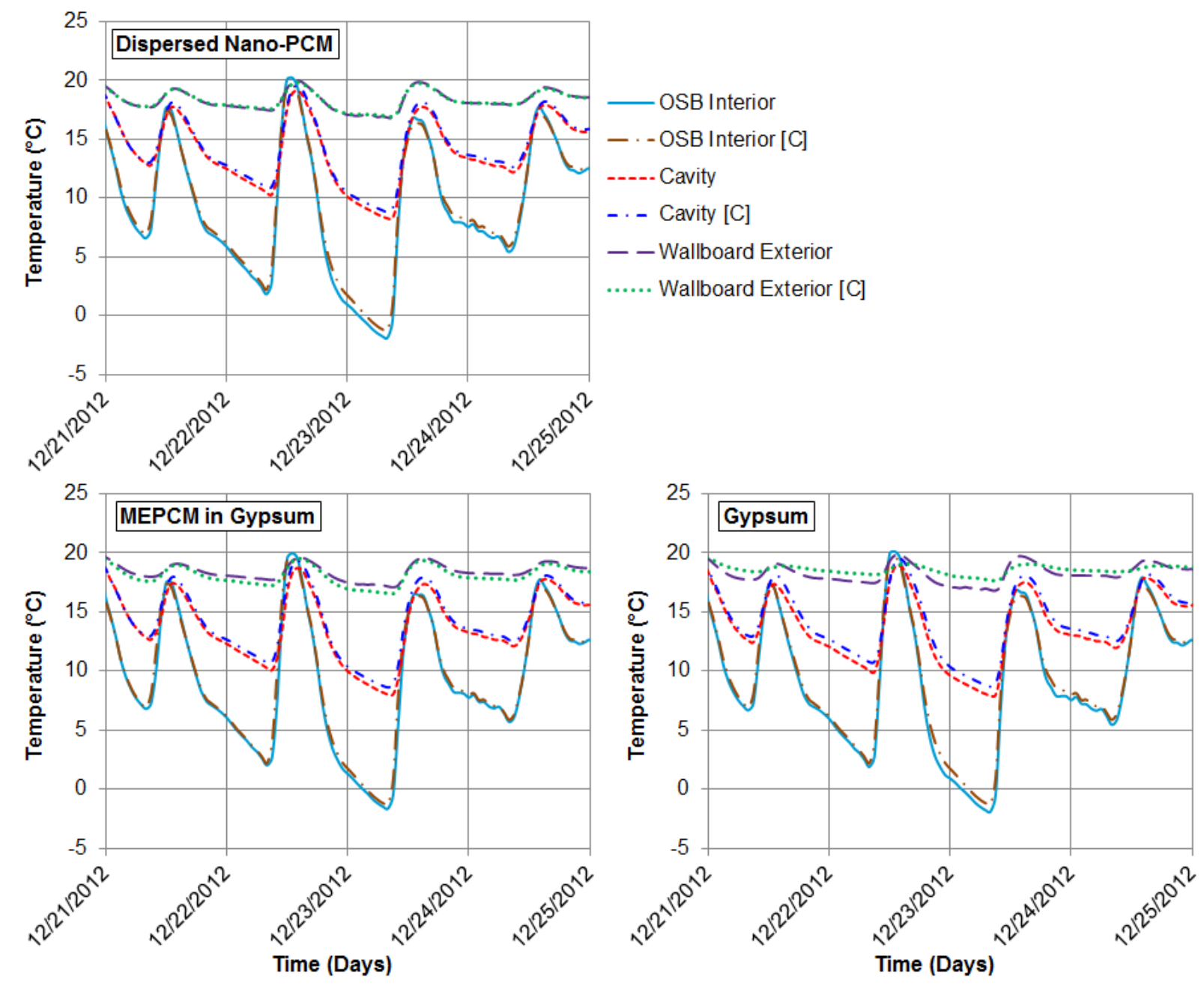

Figure 17. Comparison of model calculations with temperature data (winter).

Figure 18 compares the calculated heat fluxes at the wallboard exterior to the measured heat fluxes in Test wall 2. The HFTs were incorporated in the model geometry using the same dimensions and material properties as the HFTs installed in the test walls. There is reasonable agreement between the calculations and experimental data for the 'Dispersed Nano-PCM' and 'MEPCM in Gypsum' sections. At peak heat flux conditions (positive and negative), the calculations are within 5-20\% of the measured heat fluxes. Again, the calculations of the 'Gypsum' section showed significant differences from the measurements, especially at the peak heat flux conditions. These difference are possibly, at least in part, the result of errors in measurements caused by the air gaps in the 'Gypsum' cavity. 


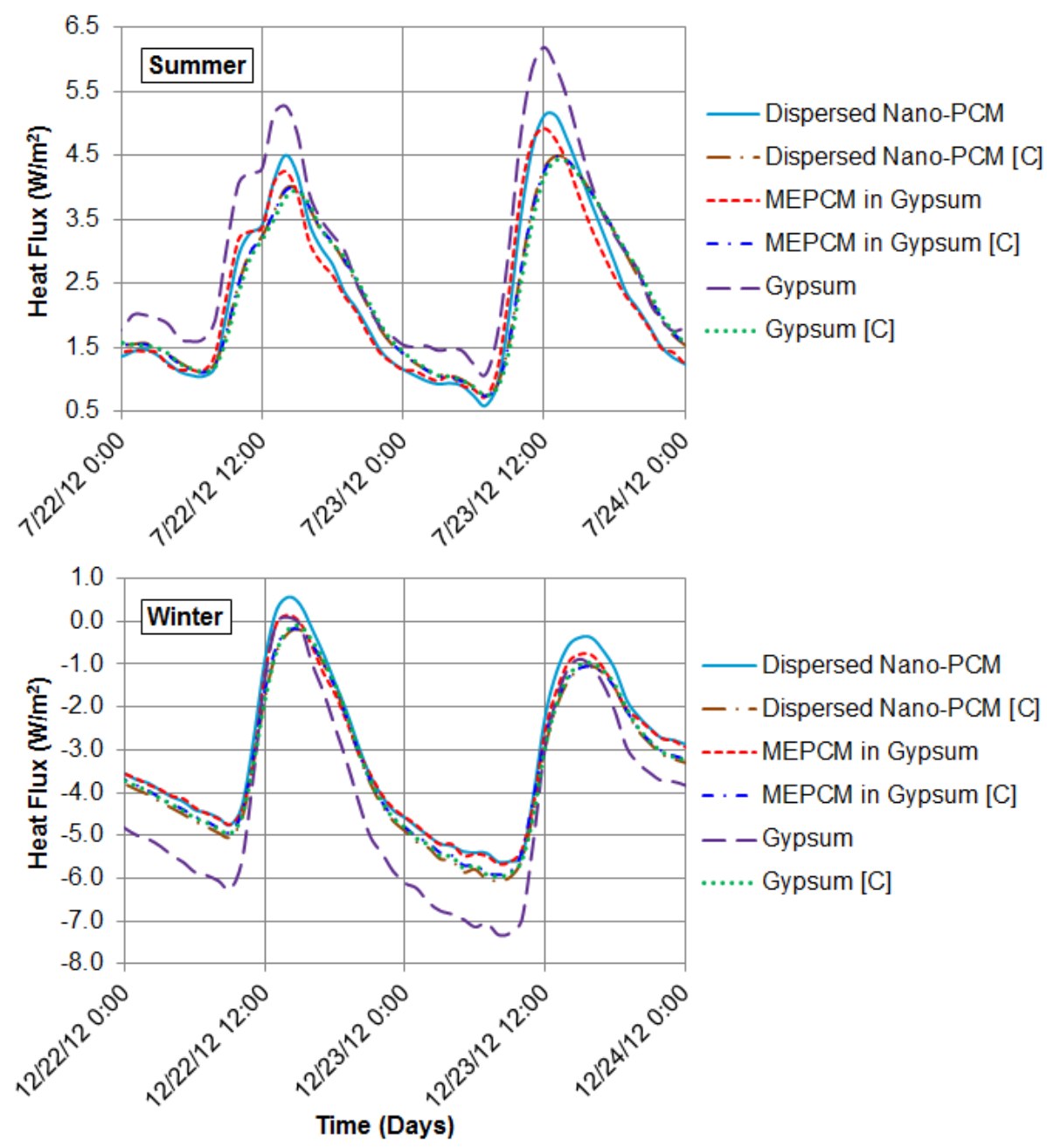

Figure 18. Comparison of model calculations with heat flux data.

In summary, the numerical models of the sections containing the PCM wallboards adequately simulate Test wall 2, and can be utilized for estimating the annual wall-generated heating and cooling loads in a model building.

\section{Annual Simulation in Charleston using TMY3 Data}

For the annual simulations, only the 'Dispersed Nano-PCM' gypsum wallboard was considered for comparison with a regular gypsum wallboard. Annual simulations were done using typical meteorological year (TMY3) ${ }^{4}$ weather data for Charleston. EnergyPlus ${ }^{5}$ was used to create input files of hourly solar radiation and exterior heat transfer coefficients for the different wall orientations. The following external $\left(q_{\text {ext }}\right)$ and internal $\left(q_{\text {int }}\right)$ heat flux boundary condition were imposed on each wall:

$$
q_{\text {ext }}=\alpha q_{\text {solar }}+h_{\text {ext }}\left(T_{\text {out }}-T_{\text {surf }}\right)+\varepsilon \sigma\left[\left(1-F_{\text {sky }}\right)\left(T_{\text {out }}^{4}-T_{\text {surf }}^{4}\right)+F_{\text {sky }}\left(T_{\text {sky }}^{4}-T_{\text {surf }}^{4}\right)\right]
$$

\footnotetext{
${ }^{4}$ http://rredc.nrel.gov/solar/old data/nsrdb/1991-2005/tmy3/

5 http://apps1.eere.energy.gov/buildings/energyplus/pdfs/engineeringreference.pdf
} 


$$
q_{\text {int }}=h_{\text {int }}\left(T_{\text {room }}-T_{\text {surf }}\right)
$$

In the above equations,

$\alpha=$ Solar absorptance of the exterior wall surface, assumed to be 0.6

$\varepsilon \quad=$ Infrared emissivity of the exterior wall surface, assumed to be 0.8

$q_{\text {solar }}=$ Solar irradiance on the exterior wall surface $\left(\mathrm{W} / \mathrm{m}^{2}\right)$, from TMY3 data

$h_{\text {ext }}=$ Exterior surface heat transfer coefficient $\left(\mathrm{W} / \mathrm{m}^{2} / \mathrm{K}\right)$

$h_{\text {int }}=$ Interior surface heat transfer coefficient $\left(\mathrm{W} / \mathrm{m}^{2} / \mathrm{K}\right)$

$F_{s k y} \quad=$ Radiation view factor from sky to the wall

$T_{\text {out }}=$ Outside ambient temperature (K), from TMY3 data

$T_{\text {sky }} \quad=$ Sky temperature (K), from TMY3 data

$T_{\text {surf }}=$ Wall surface temperature $(\mathrm{K})$, exterior or interior

$T_{\text {room }}=$ Room temperature $(\mathrm{K})$

In eq. 7, the first term on the right side is the solar irradiance, the second term is the convection heat transfer and the last term is the long-wave radiation (LWR) exchange with the surroundings. The LWR heat transfer consists of radiation exchange between the exterior wall surface and the outside environment ('out'), ground and sky, and is given by:

$$
q_{\text {LWR }}=\varepsilon \sigma\left[F_{\text {out }}\left(T_{\text {out }}^{4}-T_{\text {surf }}^{4}\right)+F_{\text {ground }}\left(T_{\text {ground }}^{4}-T_{\text {surf }}^{4}\right)+F_{\text {sky }}\left(T_{\text {sky }}^{4}-T_{\text {surf }}^{4}\right)\right]
$$

For simplicity, the ground temperature is assumed to be the same as the outside air temperature $\left(T_{\text {out }}\right)$, and the above equation is reduced to:

$$
\begin{aligned}
& q_{\text {LWR }}=\varepsilon \sigma\left[\left(F_{\text {out }}+F_{\text {ground }}\right)\left(T_{\text {out }}^{4}-T_{\text {surf }}^{4}\right)+F_{\text {sky }}\left(T_{\text {sky }}^{4}-T_{\text {surf }}^{4}\right)\right] \\
& F_{\text {sky }}+F_{\text {out }}+F_{\text {ground }}=1
\end{aligned}
$$

Following Walton [1983], the view factors are calculated as:

$$
F_{s k y}=\beta[0.5(1+\cos \phi)] ; \beta=\sqrt{0.5(1+\cos \phi)}
$$

Where $\phi$ is the tilt angle of the surface from the horizontal, which is $90^{\circ}$ for the exterior walls being modeled. The following common assumptions were made for the radiation calculations:

- each surface emits or reflects diffusely and is gray and opaque,

- $\quad$ each surface is at a uniform temperature, and

- energy flux incident on or leaving a surface is evenly distributed across the surface.

The interior heat transfer coefficient $\left(h_{\text {int }}\right)$ was assumed to be $8.29 \mathrm{~W} / \mathrm{m}^{2} / \mathrm{K}$, following ASHRAE Handbook of Fundamentals ${ }^{6}$, for a non-reflective vertical surface. It was assumed that the heating and cooling systems can exactly match the instantaneous loads, so that the interior room temperature $\left(T_{\text {room }}\right)$

\footnotetext{
${ }^{6}$ https://www.ashrae.org/resources--publications/handbook
} 
floated between the heating and cooling set points but never went outside that range. No internal loads were considered.

Figure 19 shows the simplified wall geometry that was used for the annual simulations. The wall construction used in the model was ' 2 × 6 ' stud construction, i.e. it contained wood studs of $3.8 \mathrm{~cm} \times 14.0$ $\mathrm{cm}$ (1.5 inch x $5.5 \mathrm{inch})$, resulting in a cavity depth of $14.0 \mathrm{~cm}(5.5 \mathrm{inch})$. The centerline of the studs were spaced $61 \mathrm{~cm}$ apart ( 24 inch on center). The exterior side consisted of $1.3 \mathrm{~cm}$ OSB and the interior contained $1.3 \mathrm{~cm}$ wallboard, either regular gypsum or the 'Dispersed Nano-PCM' gypsum. The scope of the study is limited to the impact of the PCM-enhanced wallboard on the heat flows through the 'clear' section of the wall, i.e. no wall-wall or wall-ceiling interfaces, joints and corners, windows, etc., were considered in the model. Hence, only a small two-dimensional (2D) horizontal cross-section of the wall was modeled, extending from the stud centerline to the cavity centerline. In the following figure, the exterior boundary condition was applied to the OSB surface that is exposed to the outside and the interior boundary condition was applied to the interior wallboard surface facing the room. Symmetric boundary conditions were assumed at the stud and cavity centerlines (Figure 19).

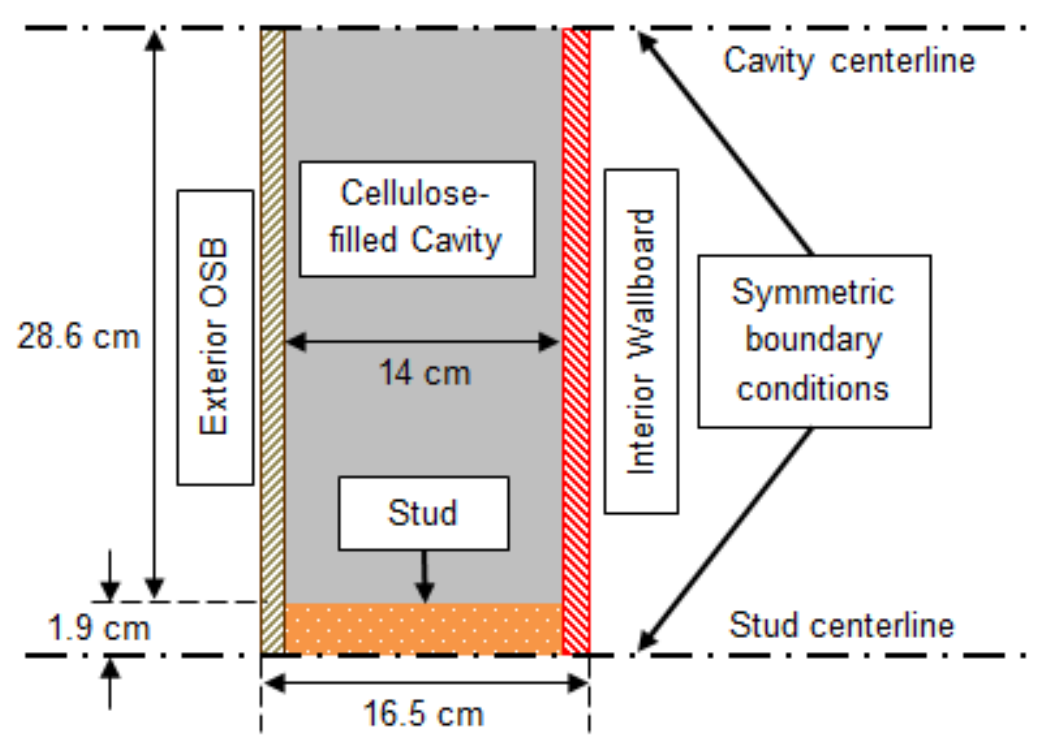

Figure 19. Simplified wall configuration used for the annual simulations.

Table 6 lists the total annual heat gains and losses through the different walls, given the exterior conditions described above. The heating and cooling set points for the room were assumed to be $20^{\circ} \mathrm{C}$ $\left(68^{\circ} \mathrm{F}\right)$ and $23.3^{\circ} \mathrm{C}\left(74^{\circ} \mathrm{F}\right)$, respectively. Different wall orientations receive different amounts of annual solar irradiance, which is reflected in the total heat gains through the walls. The annual heat losses through the different walls also varied substantially, with the highest heat loss associated with the north wall.

Since Charleston is a cooling-dominated climate, the heat gains were higher than the heat losses through all walls, except the north wall. The 'Dispersed Nano-PCM' gypsum ('NP-Gyp') wallboard reduced both heat gains and losses through each wall, although by different percent amounts. To further investigate the impact of the PCM-wallboard, the monthly heat gains and losses through the west wall are shown in Figure 20. It is interesting to note that the reduction in heat gains, due to the inclusion of the 
nano-PCM in the wallboards, are greatest during the winter and 'swing' (spring and autumn) months. In fact, the heat gains through the PCM wallboard are marginally higher during the peak summer months (Jun-Aug). Conversely, the highest reductions in the heat losses are observed during the summer and swing months.

Table 6. Annual heat gains and losses through the wall section with different wallboards and at different orientations, using $20-23.3^{\circ} \mathrm{C}\left(68-74^{\circ} \mathrm{F}\right)$ room temperature set points.

\begin{tabular}{|c|c|c|c|c|c|c|}
\hline \multirow{2}{*}{$\begin{array}{c}\text { Wall } \\
\text { Orientation }\end{array}$} & \multicolumn{2}{|c|}{ Heat gain $\left(\mathrm{Wh} / \mathrm{m}^{2}\right)$} & \multirow{2}{*}{$\begin{array}{c}\% \\
\text { Reduction }\end{array}$} & \multicolumn{2}{|c|}{ Heat loss $\left(\mathrm{Wh} / \mathrm{m}^{2}\right)$} & \multirow{2}{*}{$\begin{array}{c}\% \\
\text { Reduction }\end{array}$} \\
\hline & NP-Gyp & Gypsum & & NP-Gyp & Gypsum & \\
\hline East & 9551.20 & 10453.67 & 8.63 & -6572.94 & -7822.48 & 15.97 \\
\hline West & 9004.00 & 10145.46 & 11.25 & -6734.61 & -8141.48 & 17.28 \\
\hline North & 5479.94 & 5762.23 & 4.90 & -9622.10 & -10112.14 & 4.85 \\
\hline South & 8639.49 & 11292.24 & 23.49 & -3605.12 & -6525.87 & 44.76 \\
\hline
\end{tabular}
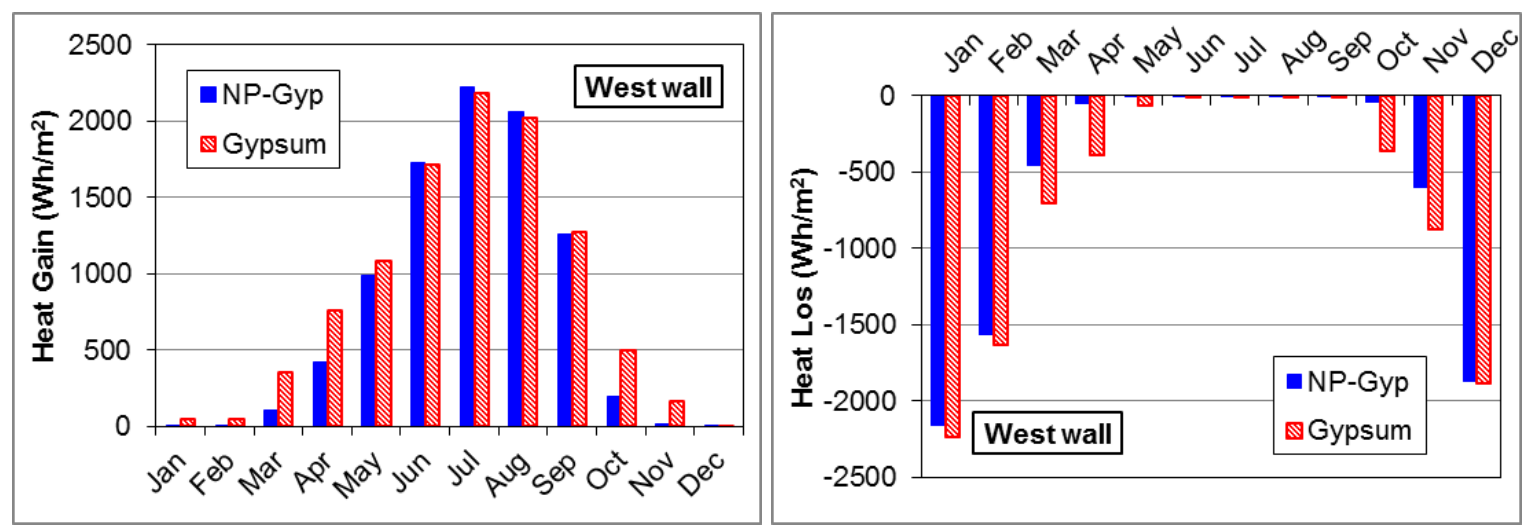

Figure 20. Monthly heat gains and losses through the west wall, with $20-23.3^{\circ} \mathrm{C}$ room temperature set points.

Childs and Stovall [2012] performed an optimization study of the impact of PCM incorporated in the cavity insulation in walls and investigated various parameters with respect to their effect on energysavings resulting from the PCM. An important finding was that the savings were sensitive to the room cooling set point with respect to the PCM phase change temperature. To further evaluate the current 'Dispersed Nano-PCM' wallboard, the west wall was further modeled at two additional interior set points, $19-21^{\circ} \mathrm{C}\left(66-70^{\circ} \mathrm{F}\right)$ and $20-22^{\circ} \mathrm{C}\left(68-72^{\circ} \mathrm{F}\right)$. The lower temperatures indicate the heating set point and the higher temperature is the cooling set point. Only the west wall was chosen for further investigation, as it exhibited median reductions in both heat gains and losses. Further, only the heat gains are considered for analysis, as Charleston lies in a cooling-dominated climate zone.

Figure 21 shows the hourly heat gain variations during three typical summer days, with hot and sunny conditions (based on the TMY3 data), with the different room temperature set points. The calculated heat gains with the gypsum and 'NP-Gyp' wallboards were practically identical at the $20-23.3^{\circ} \mathrm{C}$ and $20-22^{\circ} \mathrm{C}$ set points. However, with $19-21^{\circ} \mathrm{C}$ set point, the 'NP-Gyp' wallboard resulted in lower peak heat gains. A time-delay was also observed in the diurnal evolution of the wall heat gain with the 'NP-Gyp' wallboard, compared to the gypsum wallboard. During the late-night/early-morning hours, the heat gains through the 'NP-Gyp' wallboard were higher than the gypsum wallboard, presumably due to the freezing of the PCM releasing latent heat into the room. If some means of removing this latent heat of freezing can be devised, so it is not released into the room, higher energy savings can be realized. 

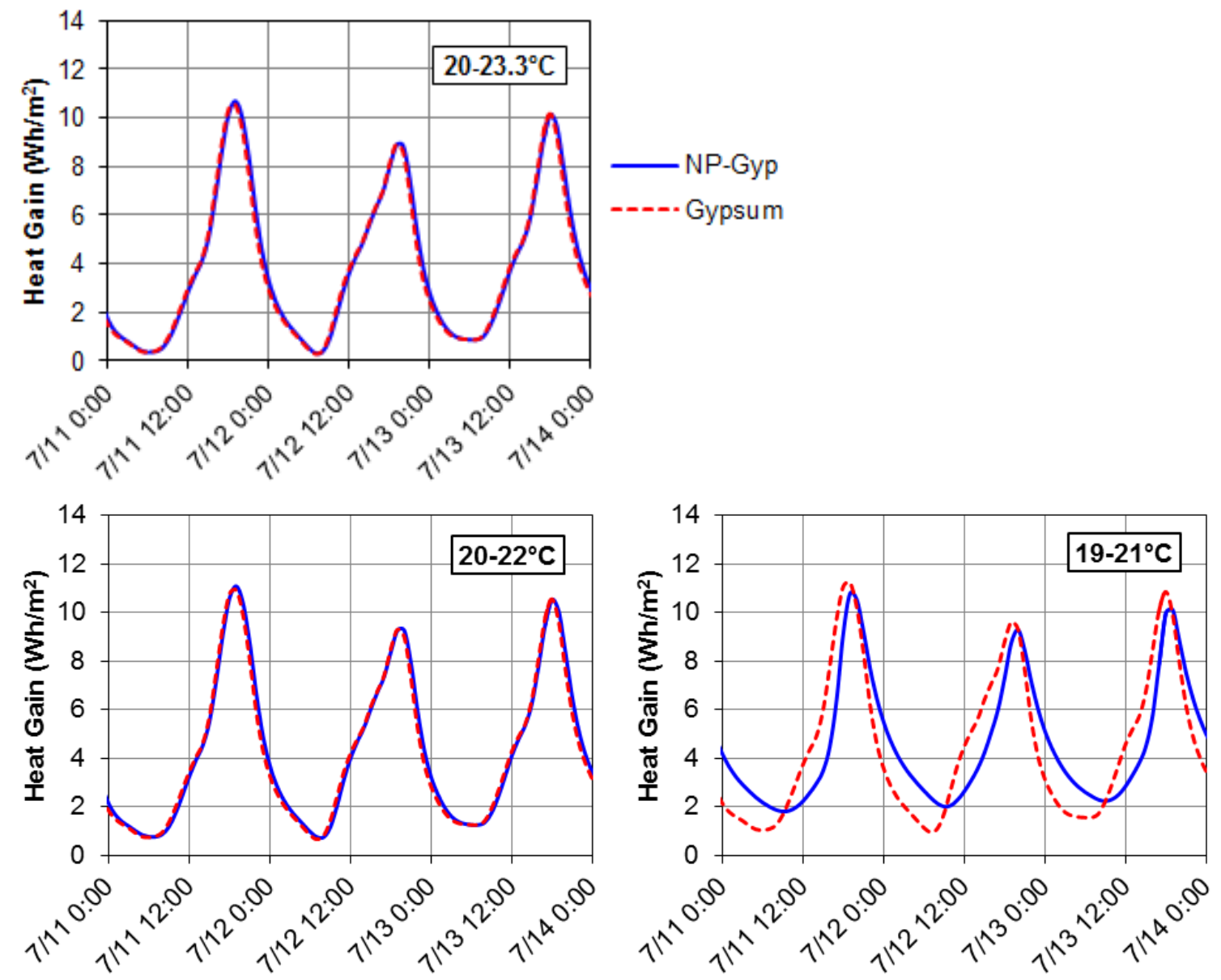

Figure 21. Heat gains through the west wall during three summer days, with different cooling set points.

An additional finding by Childs and Stovall [2012], was that the PCM, depending on several optimized parameters, was effective at time-delaying peak heat gains. This resulted in the added benefit of reduction in electricity use as the cooling equipment efficiency is related to the ambient temperature. The cooling equipment is very often placed in unconditioned space, and can remove the same amount of heat from the building interior when the outside temperatures are lower.

To determine the reduction in electricity consumption, a typical heat pump is considered, with a temperature-dependent energy efficiency ratio (EER) as shown in Figure 22. The EER data are based on ORNL testing of a heat pump with moderate performance levels (neither high-end nor with very poor efficiency). The efficiency ratio (Btu/Wh or $\mathrm{Wh} / \mathrm{Wh}$ ) can be used to convert the calculated heat gains into electricity consumption. Further, it was assumed that the cooling equipment operated only when the room temperature exceeded the cooling set point. In other words, if the room temperature remained below the cooling set point, there was no electricity consumption even if there was any heat gain through the walls. 


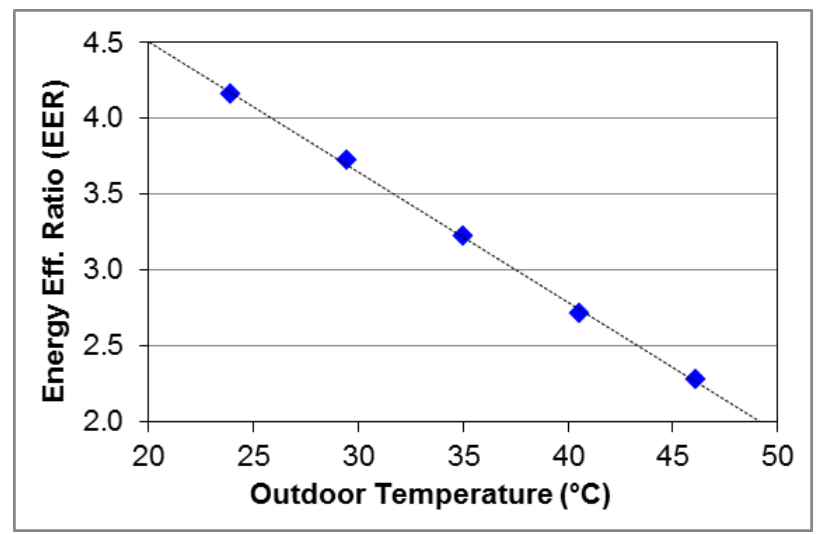

Figure 22. Energy efficiency ratio of the cooling system as a function of outdoor temperature.

Table 7 lists the calculated annual heat gains and electricity consumption with the different room temperature set points. It is interesting to note that the highest reduction in annual heat gain was observed at the $20-22^{\circ} \mathrm{C}$ set points, while the highest reduction in electricity use reduction was at $19-21^{\circ} \mathrm{C}$ set points, presumably due to the delayed heat gains caused by the 'NP-Gyp' wallboard.

Table 7. Annual heat gains and cooling electricity consumption through the west wall section with different wallboards, using variable room temperature set points.

\begin{tabular}{|c|c|c|c|c|c|c|}
\hline \multirow{2}{*}{ Set Points } & \multicolumn{2}{|c|}{ Heat gain $\left(\mathrm{Wh} / \mathrm{m}^{2}\right)$} & \multirow{2}{*}{$\begin{array}{c}\% \\
\text { Reduction }\end{array}$} & \multicolumn{2}{|c|}{ Cooling Electricity Use $\left(\mathrm{Wh} / \mathrm{m}^{2}\right)$} & \multirow{2}{*}{$\begin{array}{c}\% \\
\text { Reduction }\end{array}$} \\
\hline & NP-Gyp & Gypsum & & NP-Gyp & Gypsum & \\
\hline $19-21^{\circ} \mathrm{C}\left(66-70^{\circ} \mathrm{F}\right)$ & 12059.71 & 13698.06 & 11.96 & 3001.98 & 3467.21 & 13.42 \\
\hline $20-22^{\circ} \mathrm{C}\left(68-72^{\circ} \mathrm{F}\right)$ & 10563.03 & 12241.31 & 13.71 & 2723.32 & 3110.60 & 12.45 \\
\hline $20-23.3^{\circ} \mathrm{C}\left(68-74^{\circ} \mathrm{F}\right)$ & 9004.00 & 10145.46 & 11.25 & 2335.05 & 2601.10 & 10.23 \\
\hline
\end{tabular}

Another factor to be considered while evaluating the impact of PCM wallboards is the 'load factor (LF)'. Load factor is defined as the ratio of the peak electricity consumption to average electricity consumption during a certain time period. Lower load factors imply higher peaks, but lower average usage, and since the power plant capacities need to be designed to be able to meet peak loads, the added capacity may remain idle for extended time periods. Higher load factors and lower peak demand are beneficial for electricity providers, with potentially lower capacity and costs.

Figure 23 shows the monthly electricity consumption and load factors associated with the heat gains through the west wall at the different temperature set points. Again, the highest percentage reductions in electricity consumption were observed in the winter and 'swing' months. During the peak summer months (Jun-Sep), with the $20-23.3^{\circ} \mathrm{C}$ and $20-22^{\circ} \mathrm{C}$ set points, the electricity consumption with the 'NPGyp' wallboard was similar to or marginally greater than with the regular gypsum wallboard; the load factors were also similar. With the $19-21^{\circ} \mathrm{C}$ set points, however, the calculated electricity consumption was lower and the load factors were discernibly higher during the peak summer months with the 'NPGyp' wallboard. 

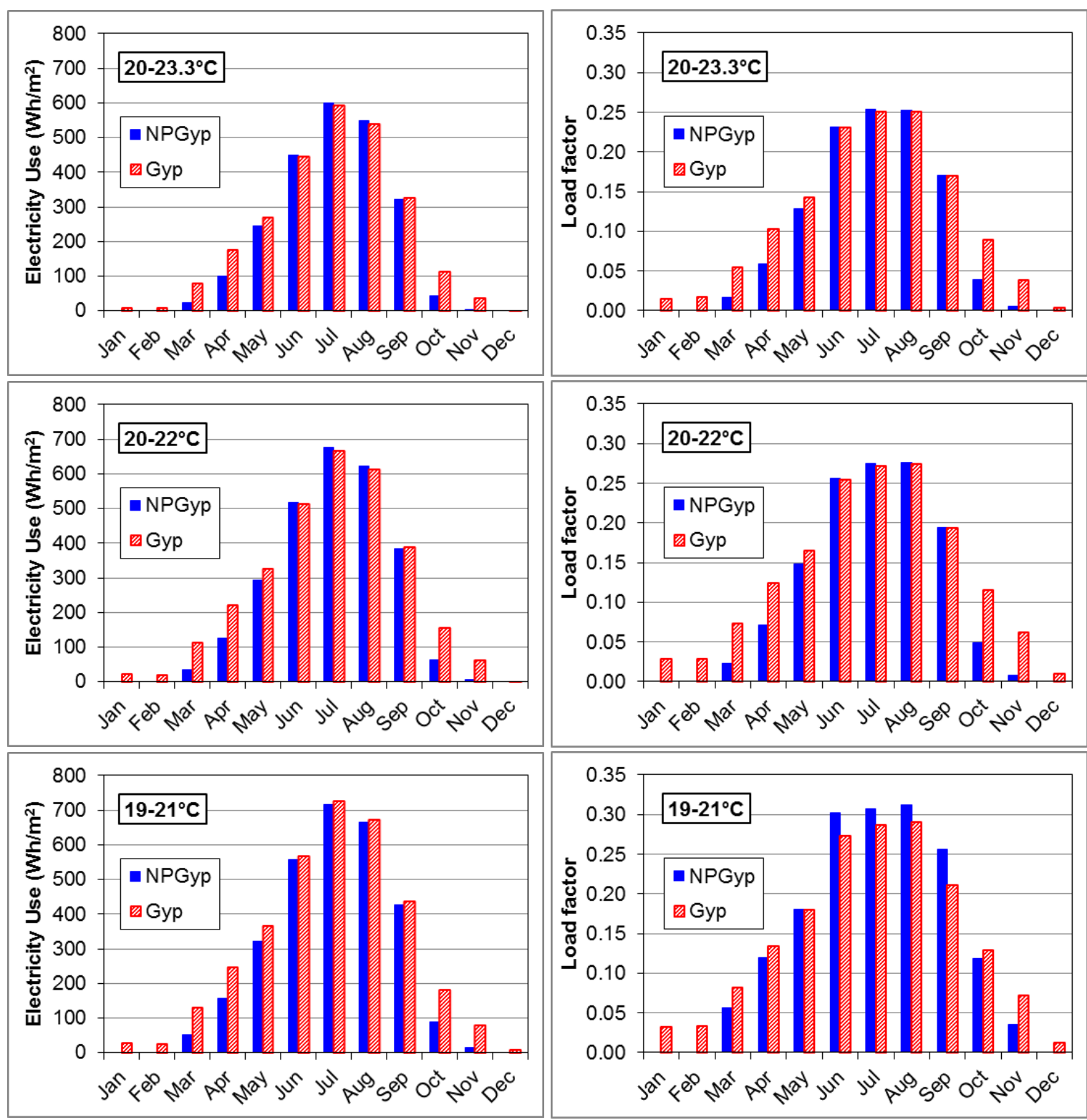

Figure 23. Monthly cooling electricity use and load factors for the west wall heat gain at different cooling set points.

In summary, the annual simulations show that the 'Dispersed Nano-PCM' gypsum wallboard can potentially reduce the heat gains and losses through the building envelope and result in reduced electricity consumption. The savings can be optimized through proper choice of the phase change temperature range of the PCM with respect to the interior heating and cooling set points. Addition factors, such as the thickness of the PCM wallboard and its location within the envelope (interior or exterior side), should be evaluated and optimized for greater energy (electricity) savings, but were outside the scope of this report.

\section{SUMMARY AND CONCLUSIONS}

This article describes the testing of four (4) prototype PCM-enhanced interior wallboards in a natural exposure test facility in Charleston, SC. Two test walls were built using wood-frames with cellulose cavity insulation. The walls were divided into sections, each containing one of the PCM wallboards. The 
PCM wallboards were produced by combining gypsum boards with PCMs using different techniques. Based on the PCM incorporation method, the wallboards were referred to as: 'PCM Soaked Gypsum', 'Three Layer Structure', 'Dispersed Nano-PCM' and 'MEPCM in Gypsum'. Each test wall also contained a section covered with regular gypsum board, which served as control to evaluate the test sections with the PCM wallboards.

The walls were instrumented using temperature and heat flux sensors. The temperature data revealed that all four PCM wallboards were expected to have undergone at least partial phase change phenomenon during the summer and shoulder months; the 'MEPCM in Gypsum' wallboard exhibited phase change activity even during winter, unlike the PCM in the other wallboards that remained frozen. The heat flux data indicated that the 'Dispersed Nano-PCM' reduced the space conditioning loads compared to a standard gypsum board, and also performed better than the control wallboard incorporating a commercial microencapsulated PCM. However, the 'PCM Soaked Gypsum' and 'Three Layer Structure' did not perform very well compared to the corresponding gypsum control section. It should be noted that in some of the wall cavities, especially in Test wall 1, air gaps were observed near the sensors, which would result in erroneous readings from the temperature and heat flux sensors. The impact of those air gaps are difficult to quantify.

Numerical modeling of Test wall 2 was performed using COMSOL. First, the model calculations were compared to experimental data for model validation. The model results of the PCM wallboard sections of Test wall 2 were in excellent agreement with measurements. Significant differences were seen between calculated results and measurements of the 'Gypsum' section of the test wall. However, these differences could potentially have been caused by measurement errors resulting from the air gaps observed near the sensors in the 'Gypsum' section of Test wall 2. Overall, the numerical models were able to adequately simulate the test wall and were used to evaluate the impact of the PCM wallboards on the wall-generated heating and cooling loads on an annual basis.

Annual simulations were performed with the 'Dispersed Nano-PCM' gypsum and gypsum, using TMY3 data. Wall assemblies, similar to Test wall 2 in Charleston, with different orientations were modeled. Different heating and cooling set points were used in the simulations to evaluate their impact on the result reductions in the wall-generated space-conditioning loads due to the PCM-wallboard. Reductions of 4.9-23.5\% and 4.9-44.8\% in calculated heat gains and losses, respectively, were observed for the different wall orientations, with $20-23.3^{\circ} \mathrm{C}$ interior temperature set points. The reduction in the cooling electricity usage with the PCM-wallboard was sensitive to interior set points and the highest reduction $(13.4 \%)$ was observed at $19-21^{\circ} \mathrm{C}$.

Further work is need to determine an optimum set of conditions to maximize the energy savings resulting from the use of PCM-enhanced wallboards. Some of the factors to be considered are removal of the latent heat of freezing so it is not released to the building interior, thickness of the wallboards and their placement within the building envelope assembly, etc. In addition, testing and/or simulations need to be performed to evaluate the performance of the PCM wallboards in other climate types.

\section{ACKNOWLEDGEMENT}

The authors would like to acknowledge the funding support for this work from the Department of Energy Small Business Innovation and Strategies Program (Recovery Act) Award No. DE-SC0003309. 


\section{REFERENCES}

1. ASTM C518-10. 2010. Standard Test Method for Steady-State Thermal Properties by Means of the Heat Flow Meter Apparatus. ASTM International, West Conshohocken, PA, USA.

2. Biwole, P.H., Eclache, P. and F. Kuznik. 2013. Phase-change materials to improve solar panel's performance. Energy and Buildings, 62: 59-67

3. Coleman, H.W. and W.G. Steele, 1989. Experimentation and Uncertainty Analysis for Engineers. John Wiley \& Sons, New York.

4. Castellon, C., Gunther, E., Mehling, H., Hiebler, S. and Cabeza, L.F., 2008. Determination of the Enthalpy of PCM as a Function of Temperature Using a Heat-Flux DSC: A Study of the Different Measurement Procedures and their Accuracy. International Journal of Energy Research, 32: 12581265.

5. Childs, K. and Stovall, T., 2012. Use of Phase Change Material in a Building Wall Assembly: A Case Study of Technical Potential in Two Climates. International High Performance Buildings Conference at Purdue, July 16-19, 2012, West Lafayette, IN, available online at http://www.conftool.com/2012Purdue/index.php?page=browseSessions\&form_session=67.

6. Drzal, L. and H. Fukushima. 2009. Expanded graphite and products produced therefrom, US Patent 7,550,529 B2.

7. Groulx, D., Samara, F. and P.H. Biwole, 2012. Natural Convection Driven Melting of Phase Change Material: Comparison of Two Methods. Proceedings of the 2012 COMSOL Conference, Boston, MA, available online at http://www.comsol.com/papers/13025/.

8. Kim, S. and Drzal, L. 2009. High latent heat storage and high thermal conductive phase change materials using exfoliated graphite nanoplatelets. Solar Energy Materials \& Solar Cells, 93: 136142.

9. Kosny, J., Biswas, K., Miller, W., and Kriner, S. 2012. Field thermal performance of naturally ventilated solar roof with PCM heat sink. Solar Energy, 86: 2504-2514.

10. Sari, A. and A. Karaipekli. 2007. Thermal conductivity and latent heat thermal energy storage characteristics of paraffin/expanded graphite composite as phase change material. Applied Thermal Engineering, 27 (8-9): 1271-1277.

11. Sharma, A., Tyagi, V.V., Chen, C.R., and D. Buddhi. 2009. Review on thermal energy storage with phase change materials and applications. Renewable and Sustainable Energy Reviews, 13 (2): 318345.

12. Shrestha, S., Miller, W., Stovall, T., Desjarlais, A., Childs, K., Porter, W., Bhandari, M., and Coley, S., 2011, Modeling PCM-enhanced insulation system and benchmarking EnergyPlus against controlled field data. Proceedings of Building Simulation 2011: 12th Conference of International Building Performance Simulation Association, p 800-807, 2011.

13. Stovall, T.K. and Tomlinson, J.J. 1995. What are the potential benefits of including latent storage in common wallboard? Journal of Solar Energy Engineering, Transactions of the ASME, 117 (4): 318-325.

14. Walton, G.N., 1983. Thermal Analysis Research Program Manual, NBSSIR 83-2655, National Bureau of Standards.

15. Xin, W., Yin Ping, Z., Wei, X., Ruo Lang, Z., Qun Li, Z. and D. Hong Fa. 2009. Review on thermal performance of phase change energy storage building envelope. Chinese Science Bulletin, 54 (6): 920-928.

16. Zalba, B., Marin, J.M., Cabeza, L.F. and H. Mehling. 2003. Review on thermal energy storage with 
phase change: materials, heat transfer analysis and applications. Applied Thermal Engineering, 23: 251-283.

17. Zhou, G., Zhang, Y., Wang, X., Lin, K. and W. Xiao. 2007. An assessment of mixed type PCMgypsum and shape-stabilized PCM plates in a building for passive solar heating. Solar Energy, 81: 1351-1360. 